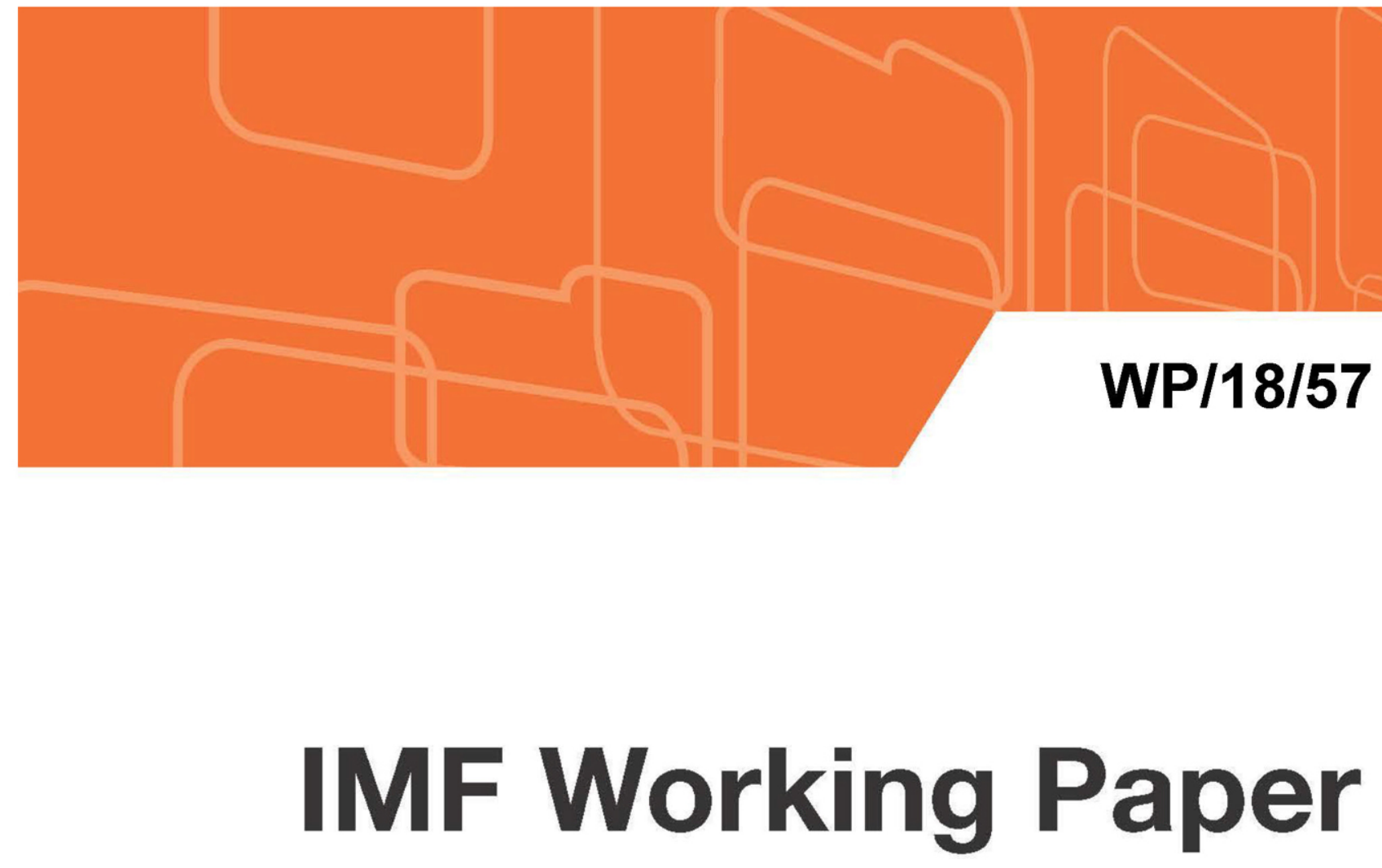

\title{
The Distributional Effects of Government Spending Shocks in Developing Economies
}

by Davide Furceri, Jun Ge, Prakash Loungani, and Giovanni Melina

IMF Working Papers describe research in progress by the author(s) and are published to elicit comments and to encourage debate. The views expressed in IMF Working Papers are those of the author(s) and do not necessarily represent the views of the IMF, its Executive Board, or IMF management.

$$
\text { I N T E R N A T I O N A L M O N E T A R Y F U N D }
$$




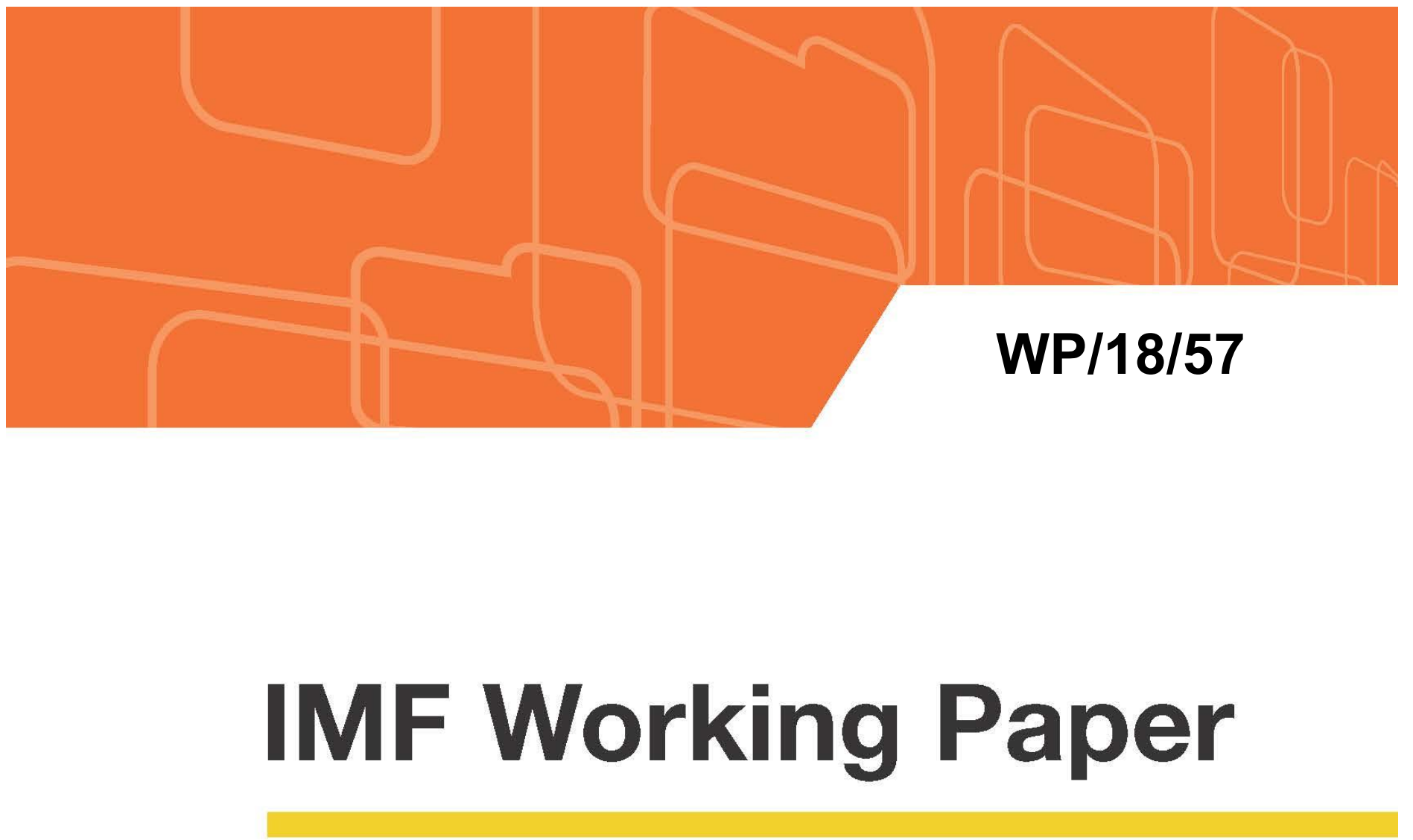

\section{The Distributional Effects of Government Spending Shocks in Developing Economies}

by Davide Furceri, Jun Ge, Prakash Loungani, and Giovanni Melina

IMF Working Papers describe research in progress by the author(s) and are published to elicit comments and to encourage debate. The views expressed in IMF Working Papers are those of the author(s) and do not necessarily represent the views of the IMF, its Executive Board, or IMF management.

$$
\text { I N T E R N A T | O N A L M O N E T A R Y F U N D }
$$




\title{
IMF Working Paper
}

\author{
Research Department
}

\section{The Distributional Effects of Government Spending Shocks in Developing Economies}

\section{Prepared by Davide Furceri, Jun Ge, Prakash Loungani, and Giovanni Melina*}

Authorized for distribution by Chris Papageorgiou

March 2018

\section{This Working Paper should not be reported as representing the views of the IMF.}

The views expressed in this Working Paper are those of the author(s) and do not necessarily represent those of the IMF, IMF policy, or of DFID. Working Papers describe research in progress by the author(s) and are published to elicit comments and to further debate.

\begin{abstract}
We construct unanticipated government spending shocks for 103 developing countries from 1990 to 2015 and study their effects on income distribution. We find that unanticipated fiscal consolidations lead to a long-lasting increase in income inequality, while fiscal expansions lower inequality. The results are robust to several measures of income distribution and size of the fiscal shocks, to an alternative identification strategy, across expansions and recessions and across country groups (low-income countries versus emerging markets). An additional contribution of the paper is the computation of the medium-term inequality multiplier. This is on average about 1 in our sample, meaning that a cumulative decrease in government spending of 1 percent of GDP over 5 years is associated with a cumulative increase in the Gini coefficient over the same period of about 1 percentage point. The multiplier is larger for total government expenditure than for public investment and consumption (with the former having larger effect), likely due to the redistributive role of transfers. Finally, we find that (unanticipated) fiscal consolidations lead to an increase in poverty.
\end{abstract}

JEL Classification Numbers: E32, D84, F02, Q41, Q43, Q48

Keywords: Fiscal policy, Fiscal shocks, Inequality, Income distribution.

Author's E-Mail Address: dfurceri@imf.org, jge@imf.org, ploungani@imf.org, gmelina@,imf.org

\footnotetext{
* We are grateful to Andy Berg, Lukas Freund, Chris Papageorgiou, Delphine Prady, and seminar participants at the IMF and the G24 meeting on macroeconomic policy and income inequality for comments and suggestions.

This working paper is part of a research project on macroeconomic policy in low-income countries supported by U.K.'s Department for International Development.
} 


\section{Contents}

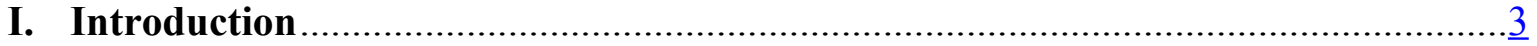

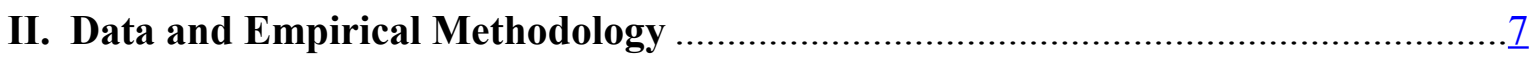

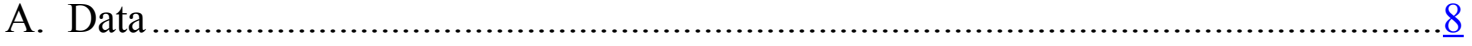

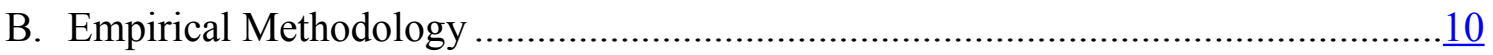

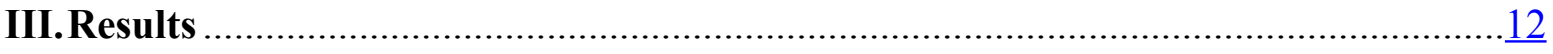

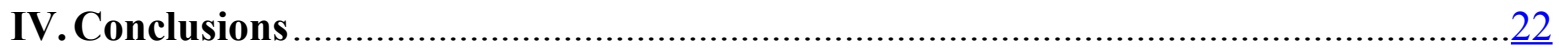

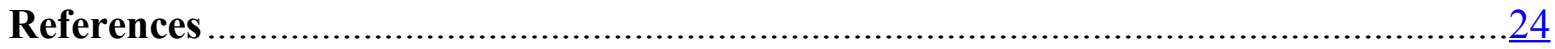

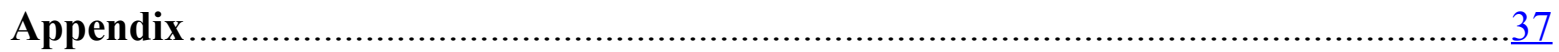

\section{List of Tables}

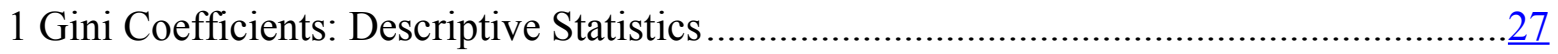

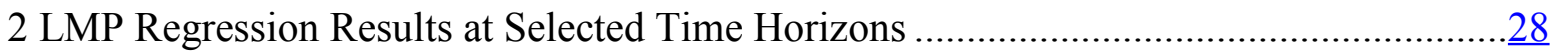

3 LMP Regression Results: Robustness Checks (5-Year Horizon) ……………………....29

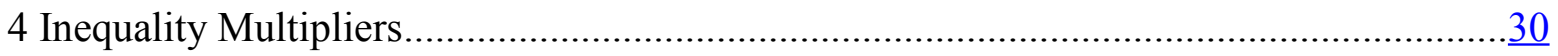

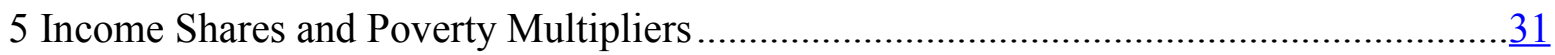

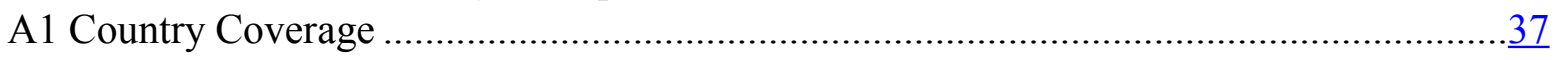

\section{List of Figures}

1 Share of Emerging Market and Developing Economies with rising inequality since 1990

2 Effect of an Unexpected Decrease in Total Government Expenditures on Net Income Inequality (Net Gini Coefficients) .................................................................................... 3 Effect of an Unexpected Decrease in Total Government Expenditures on Net Income Inequality (Net Gini) - Alternative Shocks ........................................................................ 4 Effect of an Unexpected Decrease in Total Government Expenditures on Net Income Inequality (Net Gini Coefficient) - Time Subsamples ........................................................ 5 Effect of an Unexpected Decrease in Total Government Expenditures on Net Income Inequality (Net Gini Coefficient) —Country Subsamples..................................................... 6 Effect of an Unexpected Change in Government Expenditures on Net Income Inequality (Net Gini Coefficient) — Positive versus Negative Shocks ...................................................... 7 Effect of an Unexpected Change in Government Expenditures on Net Income Inequality (Net Gini) - Large Positive versus Large Negative Shocks .................................................... 8 Effect of an Unexpected Decrease in Total Government Expenditures on Net Income Inequality (Net Gini Coefficient) - The Role of the Business Cycle ....................................... 9 Effect of an Unexpected Decrease in Government Consumption and Investment Net

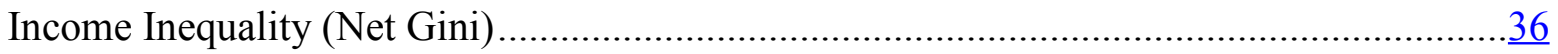

A1 Distribution of Government Expenditure Shocks in EMDE …………………….......

A2 Distribution of Government Consumption Shocks in EMDE ……...............................

A3 Distribution of Government Investment Shocks in EMDE ........................................... 


\section{INTRODUCTION}

Over the last two decades, inequality has risen in many emerging and developing economies (EMDEs) (Figure 1), including populous countries such as China and India, and remains stubbornly high in others. Although in Latin America and Sub-Saharan Africa the Gini coefficient slightly decreased on average, its level in these regions remains among the highest in the world (see e.g. IMF, 2014). At the same time, public debt-to-GDP ratios have recently increased in many EMDEs because of weaker economic activity and subdued commodity prices. Hence, many EMDEs are facing the challenge of addressing high and/or rising inequality while maintaining/regaining fiscal sustainability.

In this context, a very relevant empirical question is: What is the effect of government spending shocks on income distribution? Answering this question is important because a worsening in income inequality could reduce the political support for the government to implement consolidation measures, but also because elevated levels of inequality could harm long-run growth (Berg and Ostry, 2017).

While there is a growing body of literature on the distributional effects of fiscal policy for advanced economies, empirical evidence for EMDEs is scant and fragmented. A key reason is a methodological challenge, that is, the difficulty of identifying changes in fiscal variables that are uncorrelated with contemporaneous macroeconomic shocks, and hence that can be considered as exogenous.

The literature has so far proposed four main approaches to overcome this issue. The first is the "natural experiment" approach proposed by Barro (1981) and further developed by Ramey in subsequent papers (Ramey and Shapiro, 1998; Ramey, 2011a; Ramey, 2011b; Owyang et al., 2013). This approach uses fluctuations in military spending to identify 
government spending shocks. The second is the structural vector autoregressions (SVARs) approach developed by Blanchard and Perotti (2002), and applied to some emerging economies by Ilzetzki et al. (2013), where exogenous fiscal shocks are identified by assuming that government spending is unlikely to respond to unexpected macroeconomic shocks within the same quarter. The third method is the one proposed by Kraay $(2012,2014)$ for developing countries, which uses loans from official creditors as exogenous sources of fluctuations in government spending - we use this approach as a robustness check. Last, the fourth identification scheme, which we adopt as baseline in our paper, is the one proposed by Auerbach and Gorodnichenko (2013a, 2013b) — AG henceforth — which identifies government spending shocks as the forecast errors in government spending. ${ }^{1}$

In this paper, we adopt the AG approach for two reasons. First, data limitations (including lack of government spending data at quarterly frequency) preclude the natural experiment and the SVAR approaches for a large set of emerging and developing economies. ${ }^{2}$ The second reason is that this approach overcomes the problem of "fiscal foresight" (see Forni and Gambetti, 2010; Leeper et al., 2012; Leeper et al., 2013; and Ben Zeev and Pappa, 2015), which arises when agents and the econometrician do not have the same information set. Agents receiving news about changes in government spending in advance may alter their consumption and investment decisions well before the changes occur. An econometrician who uses the information contained in the change in actual spending would be relying on a different

\footnotetext{
${ }^{1}$ See Abiad et al. (2015) and Furceri and Li (2017) for an application of this approach to the macroeconomic effects of public investment shocks in advanced and developing economies, respectively.

${ }^{2}$ Ilzetki et al. (2013) assembled quarterly data on government spending for 24 emerging market economies. In contrast, the methodology chosen in the paper allows us to cover an unbalanced sample of 103 EMDEs (see Table A1 in the Appendix for the list of countries and dates in which observations are available).
} 
information set than that used by economic agents, and this may lead to biased estimates. By using forecast errors, the econometrician's information is aligned to that of economic agents.

After identifying government spending shocks, we use the local projections approach of Jordà (1995) to trace out the short- and medium-run responses of a set of inequality measures for a panel of 103 EMDEs over the period 1990-2016. To quantify these effects and compare them across distinct spending categories as well as across country-groups and time-periods, we follow the analogue of the three-step approach of Ramey and Zubairy (2018) to compute a measure of cumulative "inequality multiplier"- that is, the integral of the inequality response to the integral of the government spending response. This is per se a novel contribution, as to our knowledge the concept of inequality multiplier is missing in the literature. In the absence of such an approach, comparing the inequality response to fiscal shocks across states would be misleading as the ratio of government spending to GDP is state- and time-dependent, as shown by Ramey and Zubairy (2018).

The paper's main results can be summarized as follows. An unanticipated cut in government expenditure leads to a long-lasting increase in net income inequality. The mediumterm inequality multiplier is large (about 1) and statistically significant. In other words, we find that a cumulative decrease in government spending of 1 percent of GDP over 5 years is associated with a cumulative increase in the Gini coefficient over the same period of time of about 1 percentage point ${ }^{3}$ This effect is economically significant, given that the Gini coefficient is quite stable over time, and it corresponds to about 1 standard deviation of the average change in the Gini coefficient in our sample.

\footnotetext{
${ }^{3}$ In the paper we refer to the net Gini, i.e. Gini net of taxes and transfers, simply as Gini unless otherwise indicated. In addition, the Gini index is expressed in a percent scale as customary in the literature.
} 
The results are robust to several measures of income distribution. In particular, we find that a fiscal contraction leads to a decrease in the share of income held by the "poorest" 60 percent of the population, a rise in the share of income for the top 20 percent, and an increase in poverty - measured by the poverty headcount ratio. In addition, we show that the effect is larger for total government expenditure than for public investment and consumption (with the former having a larger effect), likely due to the redistributive role of transfers ${ }^{4}$. For the sake of robustness, we deploy several other checks for endogeneity and omitted bias, different measures of fiscal shocks, the size and sign of fiscal shocks, the state of the business cycle (expansions and recessions), and the level of development (low-income countries versus emerging markets).

The paper contributes to the literature on the effects of fiscal policy shocks on income distribution and inequality. One obvious feature that differentiates our study from the bulk of contributions on the topic is that we focus on EMDEs while almost all other papers look at advanced economies. Ball et al. (2013) use episodes of fiscal consolidation for a sample of 17 OECD countries over a period approximately coinciding with the Great Moderation and find that fiscal consolidation has typically had significant distributional effects by raising inequality, decreasing the labor share of income and increasing long-term unemployment. Also drawing on evidence for OECD countries, Woo et al. (2017) find that spending-based adjustments tend to worsen inequality more significantly—relative to tax-based adjustments—and that progressive taxation and targeted social benefits can help offset some of the adverse distributional impacts. These results echo those of Agnello and Sousa (2014), who find that, in industrialized economies, income inequality significantly rises during periods of expenditure-

\footnotetext{
${ }^{4}$ Data limitation preclude to directly compute the distributional effect of transfers in isolation.
} 
driven fiscal consolidations and that tax hikes have an equalizing effect. The closest contribution to ours is that of Furceri and $\mathrm{Li}$ (2017), which looks at the macroeconomic effects of public investment in developing economies using a similar methodology, and provides a first attempt in examining the effect of public investment shocks on inequality. While their focus is on the determinants of the public investment multiplier, we compare the effects of various types of government spending shocks on several measures of inequality. In addition, we use the novel inequality multiplier to compare effects across an array of states. Relative to the studies on advanced economies, we do not investigate the effects of tax shocks. The reason is that our approach is not suitable for this purpose: since revenues automatically respond to changes in economic activity (see Blanchard and Perotti, 2002 among many others), it is hard to identify exogenous changes in revenues from unexpected changes in economic activity, and narrative measures of discretionary tax changes are not available for such a wide sample of EMDEs.

The rest of the paper is organized as follows. Section II describes the data and presents the empirical methodology used to assess the distributional effects of government spending. Section III presents the main findings and reports several robustness checks. Finally, Section IV concludes.

\section{Data And Empirical Methodology}

This section discusses the data and explains the empirical methodology employed in the analysis. 


\section{A. Data}

\section{Fiscal shocks}

In order to estimate the causal effect of government expenditures on inequality, we first need to construct unanticipated government spending shocks. We follow the approach proposed by AG and identify unanticipated changes in government expenditures using forecast errors. In particular, we use the forecast errors from various vintages of the IMF World Economic Outlook (WEO) publications, which have a good time series and cross-sectional coverage of government expenditure forecasts for EMDEs. In this framework, government spending shocks $(F E)$ are computed as the difference between the growth rate of actual government spending $(\Delta \ln G)$ and the growth rate forecasted by IMF analysts as of October of the same year $\left(\Delta \ln G^{E}\right)$ :

$F E_{i, t}=\Delta \ln G_{i, t}-\Delta \ln G_{i, t}^{E}=\left(\ln G_{i, t}^{a p r, 2017}-\ln G_{i, t-1}^{a p r, 2017}\right)-\left(\ln G_{i, t}^{o c t, t}-\ln G_{i, t-1}^{o c t, t}\right)$

where $i$ and $t$ denote the cross-sectional and time dimension, respectively. ${ }^{5}$

As discussed in the introduction, this methodology solves by construction the problem of "fiscal foresight" (see Forni and Gambetti, 2010; Leeper et al., 2012; Leeper et al., 2013; and Ben Zeev and Pappa, 2015). While relying on a different information set than that used by economic agents would lead to inconsistent estimates, by using forecast errors, the AG methodology brings the two information sets into closer alignment.

\footnotetext{
${ }^{5}$ As demonstrated by An et al. (2018), WEO forecasts of fiscal variables are usually very accurate, and typically more accurate than private sector forecasts, arguably due to the continuous information flow between the IMF and finance ministries of the various member countries. Therefore, it is highly unlikely that forecast errors computed according to the methodology above might be dominated by what Ricco (2015) labels misperceptions about fiscal changes. In addition, using the forecast made in October of the same year further increases the chances that forecast errors capture unexpected policy changes rather than mere misperceptions.
} 
We use the forecasts of government expenditures made in October of the same year to minimize the likelihood that unanticipated changes in government spending arise due to the potentially endogenous response of fiscal policy to the state of the economy. In fact, even if shocks are unanticipated, they may still occur in response to business cycle conditions: for example, the government may be forced to cut spending because growth turns out to be unexpectedly weak. However, for this to materially affect our estimates, such adjustments need to happen within the same quarter when news about the state of the economy is received (i.e. between October and December). ${ }^{6}$ This is highly unlikely, as amendments to spending typically needs to be passed by parliaments and the legislative process usually takes a few months to be completed (see also Blanchard and Perotti, 2002). In any case, we later show that our findings are robust when controlling for unexpected changes in economic activity.

Figures A1-A3 in the Appendix report the distributions of government spending shocks for EMDEs. The bulk of shocks (between the $1^{\text {st }}$ and the $99^{\text {th }}$ percentile) lie between -41 and 45 percent; between -42 and 49 percent; and between -101 and 95 percent, for total government spending, consumption, and investment, respectively. ${ }^{7}$

\section{Data on inequality}

Data on income inequality are taken from the Standardized World Income Inequality Database (SWIID 5.1). ${ }^{8}$ The SWIID includes measures of net (post-tax, post-transfers) and

\footnotetext{
${ }^{6}$ All fiscal and junctural information up to October of a given year is incorporated in the forecasts made in October.

${ }^{7}$ These shocks translate into an approximately symmetric distribution of changes in government expenditures, the $1^{\text {st }}$ and $99^{\text {th }}$ percentiles of which are -5 and 5 percent of GDP, respectively.

${ }^{8}$ Income is defined as the sum of monetary and non-monetary income from labor, monetary income from capital, monetary social security transfers (including work-related insurance transfers, universal transfers, and assistance transfers), and non-monetary social assistance transfers, as well as monetary and non-monetary private transfers, less the amount of income taxes and social contributions paid. See http://fsolt.org/swiid/ for more details.
} 
market (pre-tax, pre-transfers) income inequality (Gini indices) for 174 countries from 1960 to 2013. It incorporates data from several sources (United Nations University's World Income Inequality Database, the OECD Income Distribution Database, World Bank, Eurostat, the Luxembourg Income Study) and standardizes it. ${ }^{9}$ As a robustness check, we use data on income shares from the WDI.

Gini coefficients are theoretically bounded between 0 (each reference unit receives an equal share of income) and 100 (a single reference unit receives all income). In our sample, they range from 18 to 54 for net measures and from 30 to 57 for gross measures, with higher levels of inequality typically recorded for developing countries (Table 1).

\section{B. Empirical methodology}

Using the measures of unanticipated fiscal shocks discussed above, we estimate the average impact of government spending shocks on several measures of income distribution: (i) net Gini, i.e. net of transfers and taxes; (ii) the income shares held by different percentiles of the population. In addition, we examine the effect of government spending shocks on poverty.

We use the local projection method-LPM henceforth—(Jordà, 2005) to estimate impulse-response functions. This approach has been advocated by Stock and Watson (2007) and AG, among others, as a flexible alternative that does not impose the dynamic restrictions embedded in vector autoregressions (or autoregressive-distributed lag) specifications and it is

\footnotetext{
${ }^{9}$ The SWIID starts from the Gini indexes of the Luxemburg Income Study (LIS) — considered fully comparable data - and the Gini indexes in the source data. In SWIID 5.1, the source data includes ten thousand Gini indexes from 1960 to 2014 based on all or nearly all the countries' population and for which there is sufficient information to identify the equivalence scale and welfare definition used in the calculation. Then, model-based multiple imputation is employed to estimate the missing observation of the LIS starting from the source data. See Solt (2016) for details on the methodology.
} 
particularly suited to estimating nonlinearities in the dynamic responses. The baseline regression is specified as follows:

$y_{i, t+k}=\alpha_{i}^{k}+\vartheta_{t}^{k}+\beta^{k} F E_{i, t}+\theta^{k} X_{i, t}+\varepsilon_{i, t}^{k}$,

where $y_{t}$ is the Gini coefficient; $\alpha_{i}$ are country fixed effects, included to control for all timeinvariant differences across countries (such as countries' average growth rates); $\vartheta_{t}$ are time fixed effects, included to control for global shocks such as shifts in oil prices or the global business cycle; $F E_{i, t}$ is the government spending shock discussed above; $X_{i t}$ is a set a of control variables including two lags of the shocks, as well as two lags of the Gini coefficient; $\theta^{k}$ is a vector of coefficients; and $\varepsilon_{i, t}^{k}$ is the error term.

Equation (2) is estimated for each $k=0,1, \ldots 5$, where $k=0$ is the year when the shock takes place. Impulse-response functions are computed using the estimated coefficients $\beta^{k}$, while the associated confidence bands are obtained using the estimated standard errors of the coefficients $\beta^{k}$, based on clustered robust standard errors at the country level.

\section{Computing the inequality multiplier}

As argued by Ramey and Zubairy (2018), among others, output multipliers should be calculated as the integral of the output response divided by the integral of the government spending response. We apply this concept to inequality, by computing the inequality multiplier at horizon $h$ as $\frac{\sum_{k=0}^{h} y_{t+k}}{\sum_{k=0}^{h} g_{t+k}}$, where $\sum_{k=0}^{h} y_{t+k}$ is the sum of inequality from $t$ to $t+h$ and $\sum_{k=0}^{h} g_{t+k}$ 
is the sum of the government spending variable (here, the government spending-to-GDP ratio to eliminate the measurement unit in the denominator) from $t$ to $t+h \cdot^{10}$

A more traditional way to compute this multiplier would be to take the estimated response based on unexpected expenditure growth shocks and use an ex-post conversion factor based on the sample average of the ratio of GDP to government expenditure. A problem with this approach, however, is that this ratio significantly changes over time and across countries, potentially leading to an incorrect multiplier. We address this problem by adopting the threestep approach proposed by Ramey and Zubairy (2018): (i) estimate the impulse response function of inequality to fiscal shocks using equation (2); (ii) estimate the impulse response function of the government spending-to-GDP ratio to fiscal shocks using the analogue of equation (2); compute the $h$-period ahead multipliers as the ratio of these two responses.

\section{RESUlts}

\section{Baseline}

Throughout the paper we build the figures to represent the effect of an anticipated fiscal consolidation, essentially by changing the sign of the estimated LPM coefficients reported in the tables. In fact, as emphasized in Section I, at the current juncture many EMDEs are carrying out fiscal consolidations and, hence, we are particularly interested on the effects that these consolidations may have on income inequality. Given that the employed methodology treats positive and negative fiscal shocks symmetrically, below we check whether the sign and the magnitude of the shock matter. It turns out that they do not, and that the results we draw for

\footnotetext{
${ }^{10}$ While to compute output multipliers, one would use the level of real output and government spending, for the case of inequality multipliers, we need to rescale government spending with output, to obtain a quantity comparable with the Gini index, which does not have a measurement unit.
} 
the "average" shock can be applied proportionally to ("average" and "large") fiscal consolidations.

Figure 2 and Table 2 (columns I-III) present the results obtained by estimating equation (2) using Gini coefficients for disposable income as measures of inequality. ${ }^{11}$ The figure shows the estimated effect of an unanticipated decrease in government total expenditures and the associated 90 percent confidence band (dashed lines) obtained using our baseline specification. The results show that an unanticipated fiscal contraction leads to a long-lasting and statistically significant increase in income inequality. An unanticipated decrease in government expenditures of 10 percent makes the net Gini index increase by more than 0.3 percentage points five years later. Translating this finding in terms of cumulative inequality multiplier, a cumulative decrease in government spending of 1 percent of GDP over 5 years is associated with a cumulative increase in the net Gini coefficient over the same period of about 1 percentage point (Table 4, column I). This effect is economically significant, given that the Gini coefficient is quite stable over time, and it corresponds to about 1 standard deviation of the average change in the Gini coefficient in our sample.

These effects are also of the same order of magnitude found by Ball et al. (2013) and Agnello and Sousa (2014) for advanced economies.

\section{Robustness checks}

A possible concern with the identification of government spending shocks is that they may be endogenous to output growth. While the use of forecasts made in October of the same year mitigates this concern, we check the robustness of our results to adding current and lagged

\footnotetext{
${ }^{11}$ In the remainder of the paper, we report the response of net inequality to fiscal shocks. Similar results, available upon request, are obtained for gross inequality.
} 
output growth innovations - defined as the difference between actual GDP growth and the rate forecasted by analysts in October of the same year-as controls. ${ }^{12}$ The results presented in Figure 3 (Table 3, column II) are very similar and not statistically different from the baseline. Similarly, the medium-term multiplier is very close to the one obtained in the baseline (Table 4, column II).

Another source of endogeneity could be the fact that spending shocks may occur at the same time of revenue shocks. If that is the case, our results may simply pick the response of inequality to revenue shocks rather than to spending ones. To check whether this is the case, we perform a similar exercise to the previous one using revenue surprises as controls. The results are still statistically significant and with point estimates close to the baseline (Figure 3; Table 3, column III). The medium-term multiplier (Table 4, column III) is slightly smaller than in the baseline but not different in a statistical sense.

Although the use of the forecasts made in October of each year mitigates endogeneity issues, a concern with our identification is that it focuses only on unanticipated changes in government spending occurring in the last quarter of each year and these may be less informative than changes in spending conducted over the entire year. To check whether this is the case, we repeat the analysis using the forecasts made in October of the previous year. Also in this case the response of inequality is not statistically significantly different from that reported in the baseline (Figure 3; Table 3, column IV). The point estimate of the implied inequality multiplier is lower (Table 3, column IV), although confidence bands of the two multipliers overlap with each other at conventional significance levels.

\footnotetext{
${ }^{12}$ In practice, we adopt a two-stage approach. First, we regress government spending forecast errors on GDP growth forecast errors and then use the residuals from this regression as our measure of government spending shocks.
} 
Finally, we check whether the effects of government spending shocks on inequality are robust to the inclusion of other drivers of income inequality. In particular, we consider as controls: (i) changes in trade openness (measured as the sum of exports and imports in GDP); (ii) changes in financial depth (proxied by the private credit-to-GDP ratio); (iii) political crises; and (iv) changes in the terms of trade. ${ }^{13}$ The results also in this case are very similar to those obtained in the baseline, further validating that the fiscal policy shocks identified in the analysis can be deemed as exogenous (Figure 3; Table 3, column V; Table 4, column V).

\section{Effect across country-groups and time periods}

We look at subsamples along the time dimension. Given that our sample spans between 1990 and 2016, we divide it into two equal parts — taking 2003 as the cut-off year-to verify whether the responses of inequality to government spending shocks vary across the first and the second portion of the sample. The cut-off year is an appropriate one also because many LICs experienced a structural change approximately in the mid-2000s with significantly higher average real GDP growth rates and lower real output and inflation volatilities (see, e.g., Melina and Portillo, 2018).

To investigate whether the effect has changed over time we modify equation (2) as follows:

$$
y_{i, t+k}=\alpha_{i}^{k}+\vartheta_{t}^{k}+\beta_{1}^{k} D_{i t} F E_{i, t}+\beta_{2}^{k}\left(1-D_{i t}\right) F E_{i, t}+\theta^{k} X_{i, t}+\varepsilon_{i, t}^{k}
$$

where $D$ is a dummy variable that takes value one for pre-2003 observations and zero for post2003. The results reported in Figure 4 suggest that the responses of inequality to government

\footnotetext{
${ }^{13}$ The source of the data for these variables are IMF WEO; Lane and Milesi Ferretti (2007); the World Bank Development Indicators; Leaven and Valencia (2012).
} 
spending shocks are rather stable across time, with subsample estimates and multipliers effects (Table 4, column VI-VII) not differing significantly from those obtained for the full sample.

The countries in our sample vary significantly by their level of per-capita income. To check whether the results vary across different income groups, we distinguish between Emerging Markets (EMs) and Low-Income Countries (LICs) by using a variant of equation (3), where $D$ is now a dummy variable that takes value one for EMs and zero for LICs. Figure 5 shows that the responses of inequality to government spending shocks in EMs tend to be larger than in LICs, but the differences are not statistically significantly different from each other, as well as from the results for the entire sample. Interestingly, while the point estimate of the impulse response is larger for EMs than for LICs, the point estimate of the medium-term multiplier is larger in the latter group (Table 4, column VIII-IX). The reason is that the average effect of fiscal shocks on the government spending-to-GDP-ratio is smaller in LICs than in EMs. This is one of those instances in which failing to compute the inequality multiplier would lead to drawing incorrect conclusions regarding the magnitude of the effect of fiscal shocks on inequality.

\section{Sign and magnitude of the fiscal shocks}

As explained at the beginning of this section, an interesting question is whether the sign

of government spending shocks matter-that is, whether we can safely apply the average response of inequality to fiscal shocks interchangeably across fiscal expansions and consolidations. To answer this question, we estimate a version of equation (3) where $D$ is a dummy variable that takes value one for positive shocks and zero otherwise. In Figure 6, we report the responses of net inequality to positive and negative shocks along the baseline average responses. The results suggest that the response of inequality to fiscal consolidation is 
not statistically different from the response to fiscal expansions. In addition, Table 4 (column $\mathrm{X}$ and $\mathrm{XI}$ ) shows that the inequality multiplier is virtually the same across the two cases. ${ }^{14}$ This means that the conclusions we draw from the average case can be applied to both types of fiscal actions.

Second, we check whether the size of the fiscal shock matters - that is, whether the effect of an exogenous change in government spending on inequality depends on the size of the shock. For this purpose, we estimate the following equation:

$y_{i, t+k}=\alpha_{i}^{k}+\vartheta_{t}^{k}+\beta_{1}^{k} D_{i t}{ }^{1} F E_{i, t}+\beta_{2}^{k} D_{i t}{ }^{2} F E_{i, t}+\beta_{3}^{k}\left(1-D_{i t}{ }^{1}-D_{i t}{ }^{2}\right) F E_{i, t}+\theta^{k} X_{i, t}+\varepsilon_{i, t}^{k}$

where $D^{l}$ is a dummy variable that takes value one for large positive government spending shocks - greater than the $75^{\text {th }}$ percentile (5\%) - and zero otherwise; $D^{2}$ is a dummy variable that takes value one for large negative government spending shocks - smaller than the $25^{\text {th }}$ percentile $(-6 \%)$ - and zero otherwise. ${ }^{15}$ In Figure 7 we report the responses of inequality to large positive shocks, large negative shocks, along the baseline average responses. ${ }^{16}$ While the point estimate of the inequality multiplier in the case of large negative shocks is slightly smaller than in the case of large positive shocks, the two are not statistically different from each other (Table 4, columns XII and XIII). Taken together, these results suggest that neither the size nor the sign of the shocks significantly affect the response of inequality to government spending shocks.

\footnotetext{
${ }^{14}$ Note that the sign of the estimated coefficients and implied multiplier is also the same (negative) because negative spending shocks deliver an increase in net inequality and vice versa.

${ }^{15}$ Note that the shocks are ranked unconditionally across countries and years.

${ }^{16}$ For comparability purposes, we report the response of inequality to positive fiscal shocks with the opposite sign.
} 


\section{State dependent multipliers}

Next, we check whether the responses of inequality to fiscal shocks vary across states of the business cycle - that is, depending on whether the economy is in recessions or expansions. This question is important given that several contributions (see, e.g., Batini et al., 2012; Auerbach and Gorodnichenko 2013a, 2013b; Blanchard and Leigh 2013; Abiad et al. 2015; Furceri and Li, 2017) find a different output response to fiscal shocks across states of the business cycle. It is also policy relevant at the current juncture, given that several EMDEs are adopting fiscal consolidation measures in a period of weak economic activity. To answer this question, we use a smooth-transition-function approach as in Auerbach and Gorodnichenko (2013b). We modify equation (2) as follows:

$y_{i, t+k}-y_{i, t-1}=\alpha_{i}^{k}+\vartheta_{t}^{k}+\beta_{1}^{k} G\left(z_{i t}\right) F E_{i, t}+\beta_{2}^{k}\left(1-G\left(z_{i t}\right)\right) F E_{i, t}+\theta^{k} X_{i, t}+\varepsilon_{i, t}^{k}$

with $G\left(z_{i t}\right)=\frac{\exp \left(-\gamma z_{i t}\right)}{1+\exp \left(-\gamma z_{i t}\right)}, \quad \gamma>0$, in which $\mathrm{z}$ is an indicator of the business cycle, normalized to have zero mean and unit variance and $G\left(z_{i t}\right)$ is the corresponding smooth transition function. We use real GDP growth as a measure of the business cycle. ${ }^{17}$ As discussed in AG, the local projection approach to estimating non-linear effects is equivalent to the smooth transition autoregressive (STAR) model developed by Granger and Teravistra (1993). The main advantage of this approach relative to estimating STVARs for each regime is that it uses a larger number of observations to compute the impulse response functions of the dependent variables of interest, improving the stability and precision of the estimates. This estimation

\footnotetext{
${ }^{17}$ As in Abiad et al (2015) we set $\gamma=1.5$. The results do not qualitatively change if we use alternative values of $\gamma$. The results are similar to those obtained a measure of output gap-computed using an HP filter with a smoothness parameter equal to 100 .
} 
strategy can also more easily handle the potential correlation of the standard errors within countries, by clustering at the country level.

Figure 8 reports the responses of net inequality to a government spending contraction across recessions and expansions, along with the average response. Although the point estimates of the impulse responses are larger in expansions than in recessions, the inequality multiplier (Table 4, columns XIV and XV) does not significantly differ across the two states, as the effect of the fiscal shock on the government-spending ratio is larger in expansions than recessions. This is another example where failure to compute the inequality multiplier would lead to wrong conclusions.

\section{Components of government expenditures}

This section looks at the composition of government expenditures, by disentangling the effects that government consumption and investment have on inequality. ${ }^{18}$ This distinction is important because while public investment augments the productivity of private inputs for production, public consumption is largely unproductive. To this end, we construct unexpected government consumption and investment shocks $-F E^{C}$ and $F E^{I}$ respectively-in an analogous way as we do for total government expenditures (as explained in Section II), and replace $F E$ in equation (2) with the newly constructed fiscal shocks, one at a time.

The resulting response functions are reported in Figure 9 (Table 2, columns IV-IX). A reduction in both types of government expenditure, on average, have a persistent and negative effect on inequality. An unexpected decrease in government consumption (investment) by 10

\footnotetext{
${ }^{18}$ Limited data availability for government transfers forecasts preclude examining the effect of government transfers shocks on inequality.
} 
percent reduces the Gini index over the medium-term by about $0.08(0.15)$ percentage point, with the effect of investment being similar to that computed by Furceri and Li (2017). While the point estimates are larger for consumption than investment, the inequality multiplier is larger for investment than for consumption, since the response of total government spendingto-GDP is larger for government consumption than investment (Table 4, columns XVI-XVII). This is intuitive as government consumption represents a significantly larger share of spending than public investment. In particular, while we find that the medium-term inequality multiplier associated to government consumption is around 0.2 and not statistically significant, and the multiplier associated to investment is about 0.7 . Both multipliers are lower than that of total government expenditures likely because the latter include transfers, which have a direct redistribution role by directly affecting net inequality.

\section{Other distributional measures}

The Gini index is the most commonly used measured of income inequality, mostly owing to its wider availability compared to other measures. However, some of the observations in the SWIID database are obtained by model-based imputations and therefore subject to measurement errors (Solt, 2016). ${ }^{19}$ To check the validity of our results, we re-examine the effect of fiscal shocks on income shares-taken from the WDI. Since these data are only available for few time-observations within each country, we estimate equation (2) using as dependent variable the average income share from $t$ to $t+5$. The results, reported in Table 5 (columns I-V), confirm that fiscal consolidations lead to an increase in inequality. In particular, we find that a cumulative decrease in government spending of 1 percent of GDP is associated

\footnotetext{
${ }^{19}$ The index is also criticized for being more sensitive to the income of the middle class and not capturing the exact distribution of income as identified by the Lorenz curve.
} 
with a cumulative reduction (increase) in the income share held by the lowest 60 percent of the population (top 20 percent) of about 0.2 percent. The effect is economically significant as it corresponds to about 1 standard deviation of the average change in these income shares within countries.

An interesting question is whether fiscal consolidations also lead to an increase in poverty. To answer this question, we perform a similar exercise using as dependent variable the poverty headcount ratio - again taken from the WDI. Also in this case, since these data are only available for few time-observations we compute the average of the poverty measure from $t$ to $t+5$. The results reported in Table 5 (column VI) show that a cumulative decrease in government spending of 1 percent of GDP is associated with a cumulative increase in the headcount ratio of about 0.7 percent.

\section{An alternative measure of exogenous fiscal shocks}

So far, in order to identify exogenous fiscal shocks, we used a methodology that exploits unpredictable innovations to government spending. Kray (2014) proposes a methodology that focuses on predictable fiscal shocks. This procedure uses a dataset of lending by official creditors to governments in developing countries to construct an instrument for government spending. In practice, the identification exploits the typically long lags between approval and disbursement of official loans to isolate a predetermined component of government spending decided before the realization of contemporaneous shocks. Given that this spending component is highly correlated with actual spending but pre-determined relative to current economic conditions, it is used as an instrument in the estimation of output 
multipliers to government spending shocks. ${ }^{20}$ Therefore, as a last robustness check, we compute the medium-term inequality multiplier using government spending shocks identified precisely as in Kray (2014). The inequality multiplier is lower under Kray's identification scheme than under our baseline, given the stronger response of government spending to the spending shock itself. The two multipliers, however, are not statistically different from each other.

\section{Conclusions}

The empirical fiscal literature is increasingly devoting closer attention on the distributional effects of government spending shocks. So far, however, the focus has been on advanced economies and some frontier emerging markets. Using the various vintages of the IMF WEO publications, we construct unanticipated government spending shocks for 103 developing countries from 1990 to 2015 and find that, in these countries, an unanticipated fiscal contraction leads to a delayed but long-lasting increase in net income inequality. This effect is both statistically and economically significant. An additional contribution of the paper is the computation of what we label inequality multiplier, the analogue to Ramey and Zubairy's (2018) cumulative output multiplier. Robustly across a battery of specifications, our estimate of the medium-term multiplier is about 1 , that is, a(n) decrease (increase) in government expenditures of 1 percent of GDP over five years leads to an increase (decrease) in the net Gini index of about 1 percentage point.

\footnotetext{
${ }^{20}$ Kray's instrument covers 102 countries over the period 1970-2010. The country coverage largely overlaps with ours. We conduct the estimation starting from 1990 to allow better comparability to the rest of estimations in the paper.
} 
The results do not significantly differ across fiscal stimuli and consolidations, across booms and busts, or across LICs and EMs. They survive both to alternative measures of inequality—in particular, we find that fiscal consolidations increase poverty-and an alternative way of identifying fiscal shocks, namely Kray's (2014) instrument.

Total government expenditures are found to have a stronger distributional impact than government consumption or government investment alone, likely because total expenditures include government transfers, an important redistributive tool. Moreover, the effect is larger for government investment than government consumption, likely due to the stronger mediumrun effect of the former on economic activity demonstrated by the previous literature. This finding leads to the policy implication that a budget-neutral shift of the composition of government expenditures away from consumption and toward public investment could be not only output-enhancing, but it could also help reduce inequality in the medium-term. Alternatively, in the context of fiscal consolidations, prioritizing spending items is key to mitigate the distributional impacts of the policy changes. 


\section{REFERENCES}

An, Zidong., Joao Tovar Jalles, Prakash Loungani, and Ricardo Sousa. "Do IMF Fiscal Forecasts add Value?", Journal of Forecasting, 2018, forthcoming.

Abiad, Abdul, Davide Furceri and Petia Topalova. "The Macroeconomic Effects of Public Investment: Evidence from Advanced Economies," IMF Working Papers, no. 15/95, 2015.

Agnello, Luca and Ricardo M Sousa. "How Does Fiscal Consolidation Impact on In-come Inequality?," Review of Income and Wealth, Vol. 60, 2014, pp. 702-726.

Auerbach, Alan J and Yuriy Gorodnichenko. "Output Spillovers from Fiscal Policy," American Economic Review, vol. 103, no. 3, 2013a, pp. 141-146.

Auerbach, Alan J and Yuriy Gorodnichenko. " Fiscal Multipliers in Recession and Expansion," in Alberto Alesina and Francesco Giavazzi (editors), Fiscal Policy after the Financial Crisis, National Bureau of Economic Research Conference Report, 2013b, Chicago IL, University of Chicago Press, pp. 63-98.

Ball, Laurence M, Davide Furceri, Daniel Leigh and Prakash Loungani. "The Distributional Effects of Fiscal Consolidation," IMF Working Papers, No. 13/151, International Monetary Fund, 2013.

Barro, Robert. "Output Effects of Government Purchases," Journal of Political Economy, vol. 89, no. 6, 1981, pp. 1086-1121.

Batini, Nicoletta, Giovanni Callegari and Giovanni Melina. "Successful Austerity in the United States, Europe and Japan, " IMF Working Papers 12/190, International Monetary Fund, 2012.

Ben Zeev, Nadav and Evi Pappa. "Multipliers of unexpected increases in defense spending: An empirical investigation," Journal of Economic Dynamics and Control, vol. 57(C), 2015, pages 205-226.

Berg, Andrew G. and Jonathan D. Ostry. "Inequality and Unsustainable Growth: Two Sides of the Same Coin?," IMF Economic Review, 2017, in press.

Blanchard, Olivier, and Roberto Perotti. "An Empirical Characterization of the Dynamic Effects of Changes in Government Spending and Taxes on Output," The Quarterly Journal of Economics, vol. 117, no. 4, 2002, pp. 1329-1368. 
Blanchard, Olivier, \& Daniel Leigh, 2013. "Growth Forecast Errors and Fiscal Multipliers," American Economic Review, American Economic Association, vol. 103(3), pages 117120, May.

Forni, Mario, and Luca Gambetti. "Fiscal Foresight and the Effects of Government Spending," CEPR Discussion Paper, 2010.

Furceri, Davide and Bin G. Li. "The Macroeconomic (and Distributional) Effects of Public Investment in Developing Economies," IMF Working Papers, No. 17/217, International Monetary Fund, 2017.

Granger, C W J and Timo Teräsvirta. Modelling Nonlinear Economic Relationships. Oxford, Oxford University Press, 1993.

Ilzetzki, Ethan, Enrique G Mendoza and Carlos A Vegh. "How Big (Small?) are Fiscal Multipliers?," Journal of Monetary Economics, vol. 60, no. 2, 2013, pp. 239-254.

IMF. "Fiscal Policy and Income Inequality," IMF Policy Paper. Washington DC, International Monetary Fund, 2014.

Jordà, Òscar. "Estimation and Inference of Impulse Responses by Local Projections," American Economic Review, vol. 95, no. 1, 2005, pp. 161-182.

Kraay, Aart. "How Large Is the Government Spending Multiplier? Evidence from World Bank Lending," The Quarterly Journal of Economics, vol. 127, no. 2, 2012, pp. 829-887.

Kraay, Aart. 2014."Government Spending Multipliers in Developing Countries: Evidence from Lending by Official Creditors," American Economic Journal: Macroeconomics, , vol. 6 , no. 4, pp. 170-208.

Lane, Philip R. and Gian Maria Milesi-Ferretti. "The external wealth of nations mark II: Revised and extended estimates of foreign assets and liabilities, 1970-2004," Journal of International Economics, vol. 73, 2007, pp. 223-250

Leeper, Eric M, Alexander W Richter and Todd B. Walker. "Corrigendum: Quantitative Effects of Fiscal Foresight," American Economic Journal: Economic Policy, vol. 4, no. 3, 2012, pp. 283-283.

Leeper, Eric M, Todd B Walker and Shu-Chun S Yang. "Fiscal Foresight and Information Flows," Econometrica, vol. 81, no. 3, 2013, pp. 1115-1145.

Melina, Giovanni and Rafael Portillo. "Economic Fluctuations in Sub-Saharan Africa," IMF Working Papers 17/XXX, International Monetary Fund, Forthcoming, 2017. 
Owyang Michael T, Valerie A Ramey and Sarah Zubairy, 2013. "Are Government Spending Multipliers Greater during Periods of Slack? Evidence from Twentieth-Century Historical Data," American Economic Review, vol. 103, no. 3, 2013, pp. 129-134.

Ramey, Valerie, A “Identifying Government Spending Shocks: It's all in the Timing," The Quarterly Journal of Economics, vol. 126, no. 1, 2011a, pp. 1-50.

Ramey, Valerie, A "Can Government Purchases Stimulate the Economy?," Journal of Economic Literature, vol. 49, no. 3, 2011b, pp. 673-685.

Ramey, Valerie, A, and Matthew D Shapiro. "Costly capital reallocation and the effects of government spending," Carnegie-Rochester Conference Series on Public Policy, vol. 48, no. 1, 1998, pp. 145-194.

Ramey, Valerie, A, and Sarah Zubairy. "Government Spending Multipliers in Good Times and in Bad: Evidence from U.S. Historical Data," Journal of Political Economy, 2018, forthcoming.

Ricco, G. "A New Identification of Fiscal Shocks Based on the Information Flow," ECB Working Paper 1813, European Central Bank, 2015.

Solt, Frederick. "The Standardized World Income Inequality Database," Social Science Quarterly, vol. 97, 2016, 1267-1281.

Stock, James H, and Mark W Watson. "Why Has U.S. Inflation Become Harder to Forecast?" Journal of Money, Credit and Banking, vol. 39, no. 1, 2007, pp. 3-33.

Valencia, Fabian and Luc Laeven. "Systemic Banking Crises Database; An Update," IMF Working Papers, no. 12/163, International Monetary Fund, 2012.

Woo, Jaejoon, Elva Bova, Tidiane Kinda, and Yuanyan S Zhang. "Distributional Consequences of Fiscal Adjustments: What Do the Data Say?," IMF Economic Review, vol. 65 , no. 2 , 2017, pp. 273-307. 
Table 1. Gini Coefficients: Descriptive Statistics

\begin{tabular}{|c|c|c|c|c|}
\hline \multicolumn{5}{|c|}{ EMDEs (full sample) } \\
\hline & Mean & Std.dev. & Min & Max \\
\hline Net Gini & 40.26 & 8.97 & 14.76 & 67.21 \\
\hline Market Gini & 46.23 & 8.69 & 18.53 & 76.89 \\
\hline$\Delta$ Market Gini & 0.07 & 1.68 & -11.6 & 16.43 \\
\hline$\Delta$ Net Gini & 0.03 & 1.33 & -7.05 & 12.67 \\
\hline \multicolumn{5}{|c|}{ EMs } \\
\hline & Mean & Std.dev. & Min & Max \\
\hline Net Gini & 39.76 & 9.47 & 14.76 & 67.21 \\
\hline Market Gini & 45.66 & 8.8 & 18.53 & 76.89 \\
\hline$\Delta$ Market Gini & 0.1 & 1.7 & -11.6 & 16.43 \\
\hline$\Delta$ Net Gini & 0.04 & 1.29 & -7.05 & 12.67 \\
\hline \multicolumn{5}{|c|}{ LICSs } \\
\hline & Mean & Std.dev. & Min & Max \\
\hline Net Gini & 41.24 & 7.81 & 20.38 & 61.84 \\
\hline Market Gini & 47.35 & 8.37 & 24.58 & 75.36 \\
\hline$\Delta$ Market Gini & 0.01 & 1.64 & -7.09 & 9.45 \\
\hline$\Delta$ Net Gini & -0.01 & 1.41 & -4.61 & 9.16 \\
\hline
\end{tabular}


Table 2. LMP Regression Results at Selected Time Horizons

Dependent Variable: Net Inequality

\begin{tabular}{|c|c|c|c|c|c|c|c|c|c|}
\hline & \multicolumn{3}{|c|}{$\begin{array}{l}\text { (I) (II) } \\
\text { Public Expenditure Shocks }\end{array}$} & \multicolumn{3}{|c|}{ Public Consumption Shocks } & $\begin{array}{l}\text { (VII) } \\
\text { Publi }\end{array}$ & $\begin{array}{c}\text { (VIII) } \\
\text { Investment }\end{array}$ & $\begin{array}{l}\text { (IX) } \\
\text { locks }\end{array}$ \\
\hline & $\mathbf{k}=\mathbf{0}$ & $k=1$ & $\mathbf{k}=\mathbf{5}$ & $\mathbf{k}=\mathbf{0}$ & $k=1$ & $\mathbf{k}=\mathbf{5}$ & $\mathbf{k}=\mathbf{0}$ & $k=1$ & $\mathbf{k}=\mathbf{5}$ \\
\hline $\mathrm{FE}(\mathrm{t})$ & $\begin{array}{l}-0.231 \\
(0.328)\end{array}$ & $\begin{array}{l}-0.444 \\
(0.722)\end{array}$ & $\begin{array}{c}-3.381 * * * \\
(1.088)\end{array}$ & $\begin{array}{l}-0.051 \\
(0.241)\end{array}$ & $\begin{array}{l}-0.255 \\
(0.402)\end{array}$ & $\begin{array}{l}-1.393 * \\
(0.829)\end{array}$ & $\begin{array}{l}-0.160 \\
(0.110)\end{array}$ & $\begin{array}{l}-0.241 \\
(0.200)\end{array}$ & $\begin{array}{l}-0.779 * * \\
(0.378)\end{array}$ \\
\hline $\mathrm{FE}(\mathrm{t}-1)$ & $\begin{array}{l}-0.141 \\
(0.248)\end{array}$ & $\begin{array}{l}-0.236 \\
(0.491)\end{array}$ & $\begin{array}{l}-1.724 * \\
(0.958)\end{array}$ & $\begin{array}{c}0.094 \\
(0.199)\end{array}$ & $\begin{array}{l}-0.126 \\
(0.313)\end{array}$ & $\begin{array}{l}-0.187 \\
(0.454)\end{array}$ & $\begin{array}{c}0.036 \\
(0.093)\end{array}$ & $\begin{array}{c}0.028 \\
(0.173)\end{array}$ & $\begin{array}{c}0.020 \\
(0.245)\end{array}$ \\
\hline $\mathrm{FE}(\mathrm{t}-2)$ & $\begin{array}{l}-0.199 \\
(0.198)\end{array}$ & $\begin{array}{l}-0.330 \\
(0.436)\end{array}$ & $\begin{array}{l}-2.091 * * \\
(0.895)\end{array}$ & $\begin{array}{c}-0.393 * * \\
(0.156)\end{array}$ & $\begin{array}{c}-0.575 * * \\
(0.244)\end{array}$ & $\begin{array}{l}-0.990 \\
(0.794)\end{array}$ & $\begin{array}{c}0.043 \\
(0.103)\end{array}$ & $\begin{array}{c}0.075 \\
(0.166)\end{array}$ & $\begin{array}{c}0.131 \\
(0.215)\end{array}$ \\
\hline Gini(t-1) & $\begin{array}{c}1.228 * * * \\
(0.065)\end{array}$ & $\begin{array}{c}1.346^{* * *} \\
(0.116)\end{array}$ & $\begin{array}{c}0.015 \\
(0.136)\end{array}$ & $\begin{array}{c}1.284 * * * \\
(0.043)\end{array}$ & $\begin{array}{c}1.444 * * * \\
(0.086)\end{array}$ & $\begin{array}{c}0.306 * * * \\
(0.090)\end{array}$ & $\begin{array}{c}1.276 * * * \\
(0.048)\end{array}$ & $\begin{array}{c}1.442 * * * \\
(0.083)\end{array}$ & $\begin{array}{l}0.231 * \\
(0.127)\end{array}$ \\
\hline $\operatorname{Gini}(\mathrm{t}-2)$ & $\begin{array}{c}-0.202 * * * \\
(0.069)\end{array}$ & $\begin{array}{c}-0.621 * * * \\
(0.126)\end{array}$ & $\begin{array}{l}0.243 * * \\
(0.102)\end{array}$ & $\begin{array}{c}-0.288 * * * \\
(0.066)\end{array}$ & $\begin{array}{c}-0.737 * * * \\
(0.107)\end{array}$ & $\begin{array}{c}-0.189 * * \\
(0.091)\end{array}$ & $\begin{array}{c}-0.247 * * * \\
(0.071)\end{array}$ & $\begin{array}{c}-0.695 * * * \\
(0.108)\end{array}$ & $\begin{array}{l}-0.108 \\
(0.112)\end{array}$ \\
\hline Gini(t-3) & $\begin{array}{c}-0.169 * * * \\
(0.034)\end{array}$ & $\begin{array}{l}-0.070 \\
(0.076)\end{array}$ & $\begin{array}{c}-0.292 * * \\
(0.146)\end{array}$ & $\begin{array}{c}-0.131 * * * \\
(0.038)\end{array}$ & $\begin{array}{l}-0.019 \\
(0.060)\end{array}$ & $\begin{array}{l}-0.095 \\
(0.116)\end{array}$ & $\begin{array}{c}-0.183 * * * \\
(0.039)\end{array}$ & $\begin{array}{l}-0.104 \\
(0.067)\end{array}$ & $\begin{array}{l}-0.193 \\
(0.134)\end{array}$ \\
\hline Constant & $\begin{array}{c}4.831 * * * \\
(1.000)\end{array}$ & $\begin{array}{c}12.544 * * * \\
(2.271)\end{array}$ & $\begin{array}{c}39.783 * * * \\
(5.038)\end{array}$ & $\begin{array}{c}5.237 * * * \\
(0.534)\end{array}$ & $\begin{array}{c}12.415 * * * \\
(1.077)\end{array}$ & $\begin{array}{c}39.473 * * * \\
(3.056)\end{array}$ & $\begin{array}{c}6.114 * * * \\
(0.662)\end{array}$ & $\begin{array}{c}14.191 * * * \\
(1.447)\end{array}$ & $\begin{array}{c}43.922 * * * \\
(3.748)\end{array}$ \\
\hline Observations & 993 & 896 & 553 & 1,399 & 1,296 & 914 & 1,303 & 1,201 & 826 \\
\hline R-squared & 0.991 & 0.977 & 0.964 & 0.990 & 0.974 & 0.935 & 0.990 & 0.973 & 0.938 \\
\hline Year effects & Yes & Yes & Yes & Yes & Yes & Yes & Yes & Yes & Yes \\
\hline Country effects & Yes & Yes & Yes & Yes & Yes & Yes & Yes & Yes & Yes \\
\hline
\end{tabular}

Notes: Clustered robust standard errors in parentheses. ${ }^{* * *},{ }^{* *},{ }^{*}$ denote $\mathrm{p}<0.01, \mathrm{p}<0.05, \mathrm{p}<0.1$, respectively. 
Table 3. LMP Regression Results: Robustness Checks (5-Year Horizon)

\begin{tabular}{|c|c|c|c|c|c|}
\hline & $\begin{array}{c}\text { (I) } \\
\text { Baseline } \\
\mathbf{k}=\mathbf{5}\end{array}$ & $\begin{array}{c}\text { (II) } \\
\text { Growth } \\
\text { forecasts } \\
\mathbf{k}=\mathbf{5}\end{array}$ & $\begin{array}{c}\text { (III) } \\
\text { Revenue } \\
\text { shocks } \\
\mathbf{k}=\mathbf{5}\end{array}$ & $\begin{array}{c}(\mathrm{IV}) \\
\text { FS in previous } \\
\text { year } \\
\mathbf{k}=\mathbf{5}\end{array}$ & $\begin{array}{c}(\mathrm{V}) \\
\text { Additional } \\
\text { controls } \\
\mathbf{k}=\mathbf{5}\end{array}$ \\
\hline $\mathrm{FE}(\mathrm{t})$ & $\begin{array}{c}-3.381 * * * \\
(1.088)\end{array}$ & $\begin{array}{c}-3.102 * * * \\
(1.042)\end{array}$ & $\begin{array}{c}-2.694 * * \\
(1.051)\end{array}$ & $\begin{array}{c}-2.926 * * \\
(1.334)\end{array}$ & $\begin{array}{c}-2.691 * * * \\
(0.962)\end{array}$ \\
\hline $\mathrm{FE}(\mathrm{t}-1)$ & $\begin{array}{c}-1.724 * \\
(0.958)\end{array}$ & $\begin{array}{c}-1.669 * \\
(0.951)\end{array}$ & $\begin{array}{c}-1.900 * \\
(1.056)\end{array}$ & $\begin{array}{l}-1.768 \\
(1.137)\end{array}$ & $\begin{array}{l}-1.469 \\
(0.994)\end{array}$ \\
\hline $\mathrm{FE}(\mathrm{t}-2)$ & $\begin{array}{c}-2.091 * * \\
(0.895)\end{array}$ & $\begin{array}{c}-1.920 * * \\
(0.928)\end{array}$ & $\begin{array}{c}-2.000 * * \\
(0.819)\end{array}$ & $\begin{array}{l}-2.292 * \\
(1.249)\end{array}$ & $\begin{array}{c}-1.318 * * \\
(0.643)\end{array}$ \\
\hline $\operatorname{Gini}(\mathrm{t}-1)$ & $\begin{array}{c}0.015 \\
(0.136)\end{array}$ & $\begin{array}{c}0.024 \\
(0.138)\end{array}$ & $\begin{array}{c}0.025 \\
(0.137)\end{array}$ & $\begin{array}{c}0.107 \\
(0.156)\end{array}$ & $\begin{array}{l}-0.055 \\
(0.137)\end{array}$ \\
\hline $\operatorname{Gini}(\mathrm{t}-2)$ & $\begin{array}{c}0.243 * * \\
(0.102)\end{array}$ & $\begin{array}{c}0.227 * * \\
(0.101)\end{array}$ & $\begin{array}{c}0.247 * * \\
(0.103)\end{array}$ & $\begin{array}{c}0.076 \\
(0.113)\end{array}$ & $\begin{array}{c}0.254 * * \\
(0.122)\end{array}$ \\
\hline Gini(t-3) & $\begin{array}{c}-0.292 * * \\
(0.146)\end{array}$ & $\begin{array}{c}-0.287 * \\
(0.146)\end{array}$ & $\begin{array}{c}-0.279 * \\
(0.143)\end{array}$ & $\begin{array}{l}-0.181 \\
(0.146)\end{array}$ & $\begin{array}{c}-0.292 * * \\
(0.142)\end{array}$ \\
\hline Constant & $\begin{array}{c}39.783 * * * \\
(5.038)\end{array}$ & $\begin{array}{c}39.851 * * * \\
(5.098)\end{array}$ & $\begin{array}{c}38.710 * * * \\
(4.887)\end{array}$ & $\begin{array}{c}38.165^{* * *} \\
(5.176)\end{array}$ & $\begin{array}{c}42.930 * * * \\
(4.763)\end{array}$ \\
\hline Observations & 553 & 554 & 543 & 508 & 528 \\
\hline R-squared & 0.964 & 0.964 & 0.964 & 0.966 & 0.968 \\
\hline Year effects & Yes & Yes & Yes & Yes & Yes \\
\hline $\begin{array}{l}\text { Country } \\
\text { effects }\end{array}$ & Yes & Yes & Yes & Yes & Yes \\
\hline
\end{tabular}


Table 4. Inequality Multipliers

\begin{tabular}{|c|c|c|c|c|c|c|}
\hline & $\begin{array}{c}\text { (I) } \\
\text { Baseline }\end{array}$ & $\begin{array}{c}\text { (II) } \\
\text { Growth } \\
\text { Forecasts }\end{array}$ & $\begin{array}{l}\text { (III) } \\
\text { Revenue } \\
\text { Shocks }\end{array}$ & $\begin{array}{l}(\mathrm{IV}) \\
\text { FS in } \\
\text { previous } \\
\text { year }\end{array}$ & $\begin{array}{l}\text { (V) } \\
\text { Additional } \\
\text { controls }\end{array}$ & $\begin{array}{c}\text { (VI) } \\
\text { Before } 2003\end{array}$ \\
\hline Multiplier $(\mathrm{h}=5)$ & $\begin{array}{c}-0.958 * * * \\
(0.318)\end{array}$ & $\begin{array}{c}-0.997 * * * \\
(0.362)\end{array}$ & $\begin{array}{c}-0.877 * * * \\
(0.291)\end{array}$ & $\begin{array}{c}-0.461 * * \\
(0.197)\end{array}$ & $\begin{array}{c}-0.922 * * * \\
(0.315)\end{array}$ & $\begin{array}{c}-0.949 * * * \\
(0.303)\end{array}$ \\
\hline Observations & 553 & 554 & 543 & 508 & 528 & 553 \\
\hline R-squared & 0.984 & 0.984 & 0.985 & 0.985 & 0.985 & 0.985 \\
\hline Year effects & Yes & Yes & Yes & Yes & Yes & Yes \\
\hline Country effects & Yes & Yes & Yes & Yes & Yes & Yes \\
\hline & $\begin{array}{c}\text { (VII) } \\
\text { After } 2003\end{array}$ & $\begin{array}{c}\text { (VIII) } \\
\text { EMs }\end{array}$ & $\begin{array}{l}\text { (IX) } \\
\text { LICs }\end{array}$ & $\begin{array}{c}\text { (X) } \\
\text { Positive } \\
\text { Shocks } \\
\end{array}$ & $\begin{array}{c}\text { (XI) } \\
\text { Negative } \\
\text { Shocks } \\
\end{array}$ & $\begin{array}{c}\text { (XII) } \\
\text { Large Positive } \\
\text { Shocks }\end{array}$ \\
\hline Multiplier $(\mathrm{h}=5)$ & $\begin{array}{c}-0.961 * * * \\
(0.316)\end{array}$ & $\begin{array}{c}-0.645 * \\
(0.355)\end{array}$ & $\begin{array}{c}-0.160 * * * \\
(0.417)\end{array}$ & $\begin{array}{c}-1.006 * * * \\
(0.379)\end{array}$ & $\begin{array}{c}-1.008^{* * *} \\
(0.382)\end{array}$ & $\begin{array}{c}-1.005^{* * *} \\
(0.340)\end{array}$ \\
\hline Observations & 553 & 553 & 553 & 553 & 553 & 553 \\
\hline R-squared & 0.985 & 0.985 & 0.985 & 0.984 & 0.984 & 0.984 \\
\hline Year effects & Yes & Yes & Yes & Yes & Yes & Yes \\
\hline \multirow[t]{2}{*}{ Country effects } & Yes & Yes & Yes & Yes & Yes & Yes \\
\hline & $\begin{array}{c}\text { (XIII) } \\
\text { Large } \\
\text { Negative } \\
\text { Shocks } \\
\end{array}$ & Expansions & Recessions & $\begin{array}{c}\text { (XVI) } \\
\text { Government } \\
\text { Investment }\end{array}$ & $\begin{array}{l}\text { (XVII) } \\
\text { Government } \\
\text { Consumption }\end{array}$ & (XVIII) \\
\hline Multiplier $(\mathrm{h}=5)$ & $\begin{array}{c}-0.923 * * \\
(0.428)\end{array}$ & $\begin{array}{c}-0.970 * * * \\
(0.321)\end{array}$ & $\begin{array}{c}-0.959 * * * \\
(0.319)\end{array}$ & $\begin{array}{c}-0.691 * * \\
(0.315)\end{array}$ & $\begin{array}{c}-0.184 \\
(0.173)\end{array}$ & $\begin{array}{c}-0.775 * \\
(0.431)\end{array}$ \\
\hline Observations & 553 & 553 & 553 & 826 & 914 & 996 \\
\hline R-squared & 0.984 & 0.985 & 0.985 & 0.975 & 0.974 & 0.953 \\
\hline Year effects & Yes & Yes & Yes & Yes & Yes & Yes \\
\hline Country effects & Yes & Yes & Yes & Yes & Yes & Yes \\
\hline
\end{tabular}


Table 5. Income Shares and Poverty Multipliers

\begin{tabular}{|c|c|c|c|c|c|c|}
\hline & $\begin{array}{c}\text { (I) } \\
1^{\text {st }} 20 \\
\text { percent }\end{array}$ & $\begin{array}{c}2^{\text {nd }} 20 \\
\text { percent }\end{array}$ & $\begin{array}{c}\text { (III) } \\
\text { Income shares } \\
3^{\text {rd } 20} \\
\text { percent }\end{array}$ & $\begin{array}{l}4^{\text {th }} 20 \\
\text { percent }\end{array}$ & $\begin{array}{c}5^{\text {th }} 20 \\
\text { percent }\end{array}$ & $\begin{array}{c}\text { (VI) } \\
\text { Poverty } \\
\text { Head count } \\
\text { ratio }\end{array}$ \\
\hline $\begin{array}{l}\text { Multiplier } \\
(\mathrm{h}=5)\end{array}$ & $\begin{array}{c}-0.092 * * \\
(0.036)\end{array}$ & $\begin{array}{c}-0.074 * * * \\
(0.023)\end{array}$ & $\begin{array}{c}-0.050 * * * \\
(0.015)\end{array}$ & $\begin{array}{l}-0.005 \\
(0.019)\end{array}$ & $\begin{array}{c}0.221 * * * \\
(0.062)\end{array}$ & $\begin{array}{c}0.738^{* *} \\
(0.3380\end{array}$ \\
\hline Observations & 215 & 215 & 215 & 215 & 215 & 176 \\
\hline R-squared & 0.97 & 0.99 & 0.99 & 0.96 & 0.99 & 0.92 \\
\hline $\begin{array}{l}\text { Year effects } \\
\text { Country } \\
\text { effects }\end{array}$ & Yes & Yes & Yes & Yes & Yes & Yes \\
\hline
\end{tabular}


Figure 1. Share of Emerging Market and Developing Economies with rising inequality since 1990

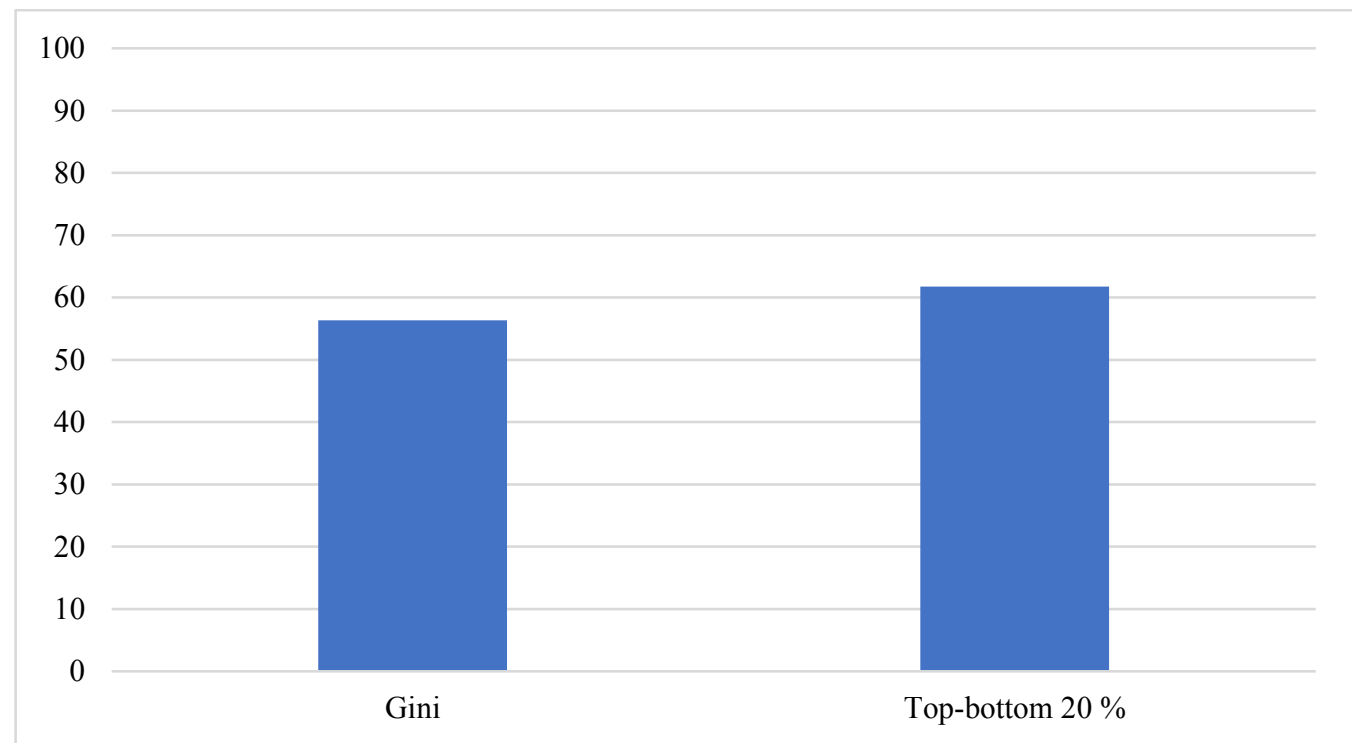

Source: Standardized World Income Inequality Database (Solt, 2016), WDI.

Figure 2. Effect of an Unexpected Decrease in Total Government Expenditures on Net Income Inequality (Net Gini Coefficients)

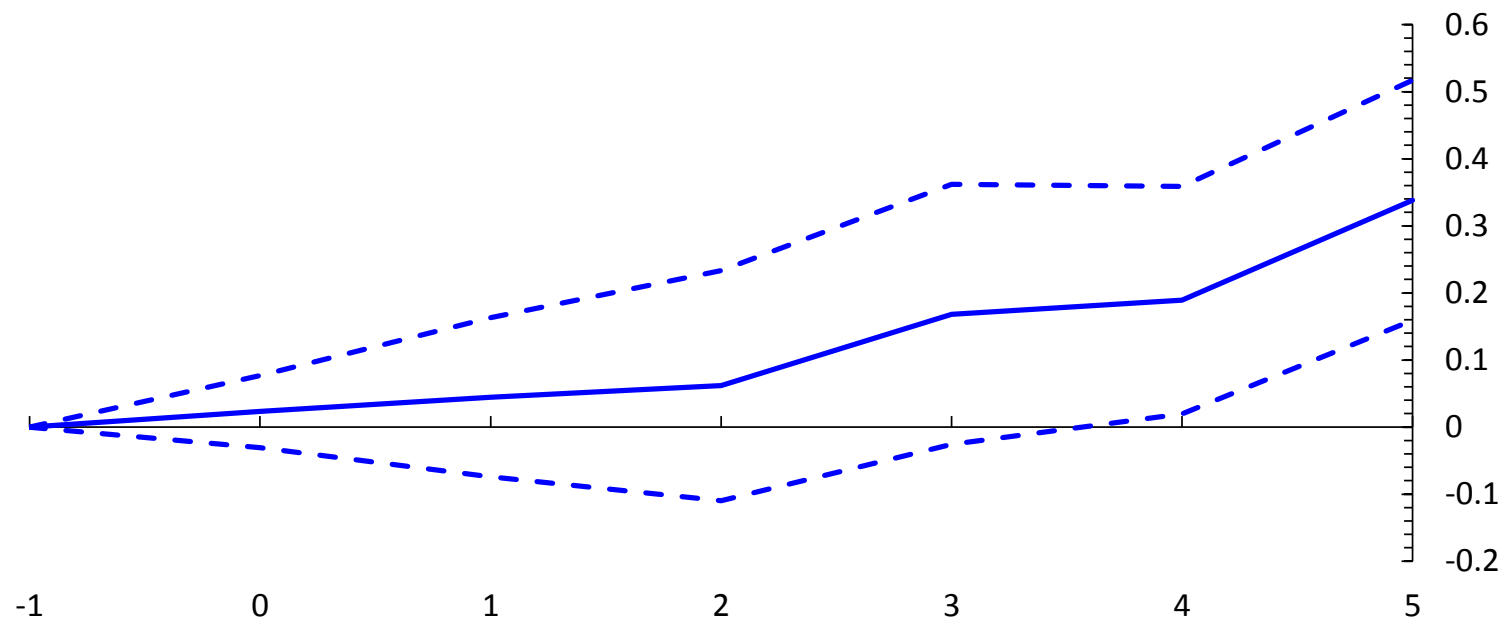

Note: $\mathrm{x}$-axes denote years; $\mathrm{t}=0$ is the year of the shock; the solid blue line denotes responses to an unanticipated 10 percent decrease in government expenditures; dashed lines denote 90 percent confidence bands. Estimates based on equation (2). 
Figure 3. Effect of an Unexpected Decrease in Total Government Expenditures on Net Income Inequality (Net Gini) - Alternative Shocks

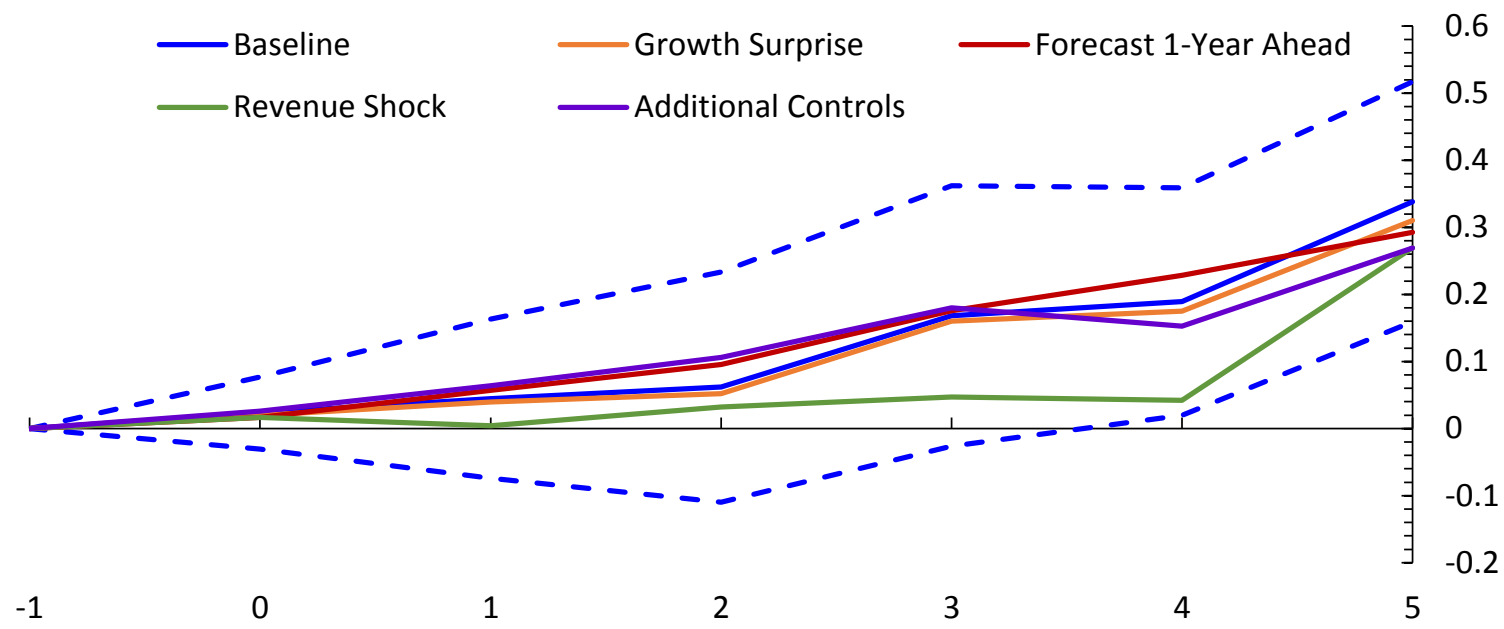

Note: $\mathrm{x}$-axes denote years; $\mathrm{t}=0$ is the year of the shock; the solid blue line denotes responses to an unanticipated 10 percent decrease in government expenditures in the baseline model; dashed lines denote 90 percent confidence bands in the baseline model; solid lines in other colors denote alternative models. Estimates based on equation (2) modified appropriately for each case.

Figure 4. Effect of an Unexpected Decrease in Total Government Expenditures on Net Income Inequality (Net Gini Coefficient)—Time Subsamples

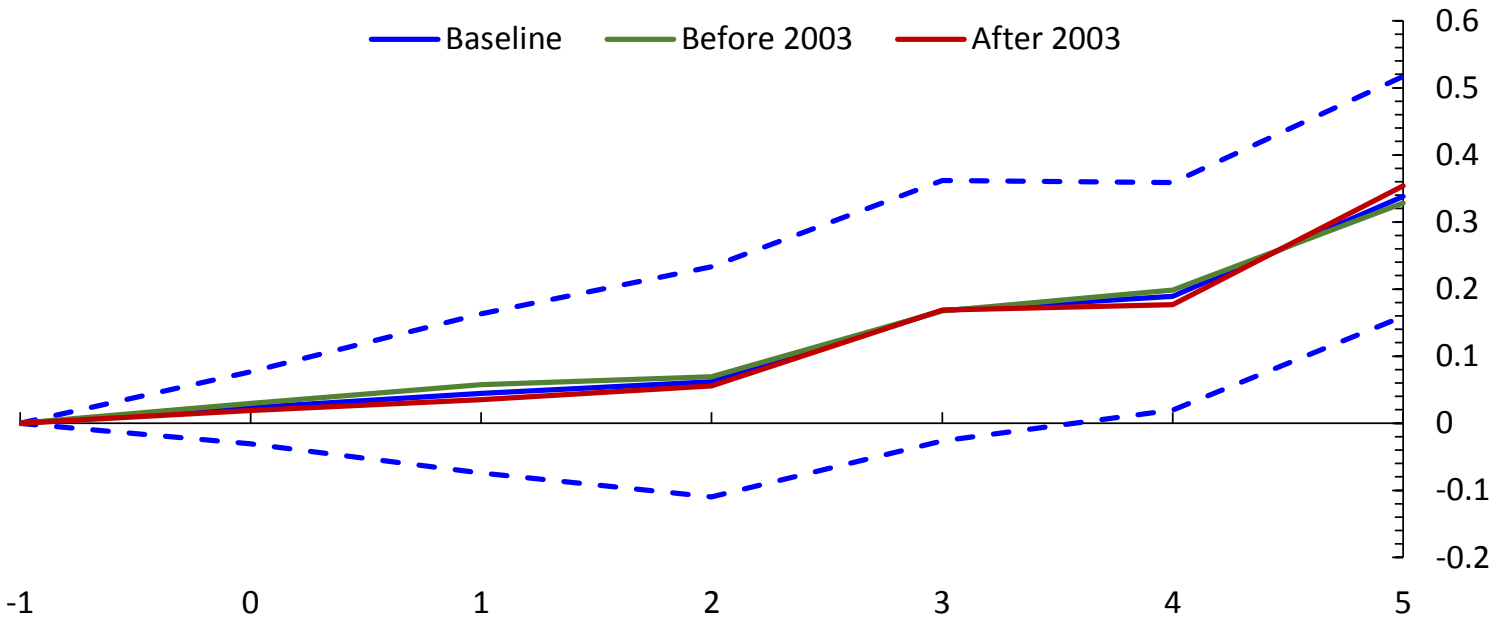

Note: $\mathrm{x}$-axes denots years; $\mathrm{t}=0$ is the year of the shock; the solid blue line denotes responses to an unanticipated 10 percent decrease in government expenditure in the baseline sample; dashed lines denote 90 percent confidence bands in the baseline sample; solid red and green lines denote alternative subsamples. Estimates based on equation (3). 
Figure 5. Effect of an Unexpected Decrease in Total Government Expenditures on Net Income Inequality (Net Gini Coefficient) — Country Subsamples

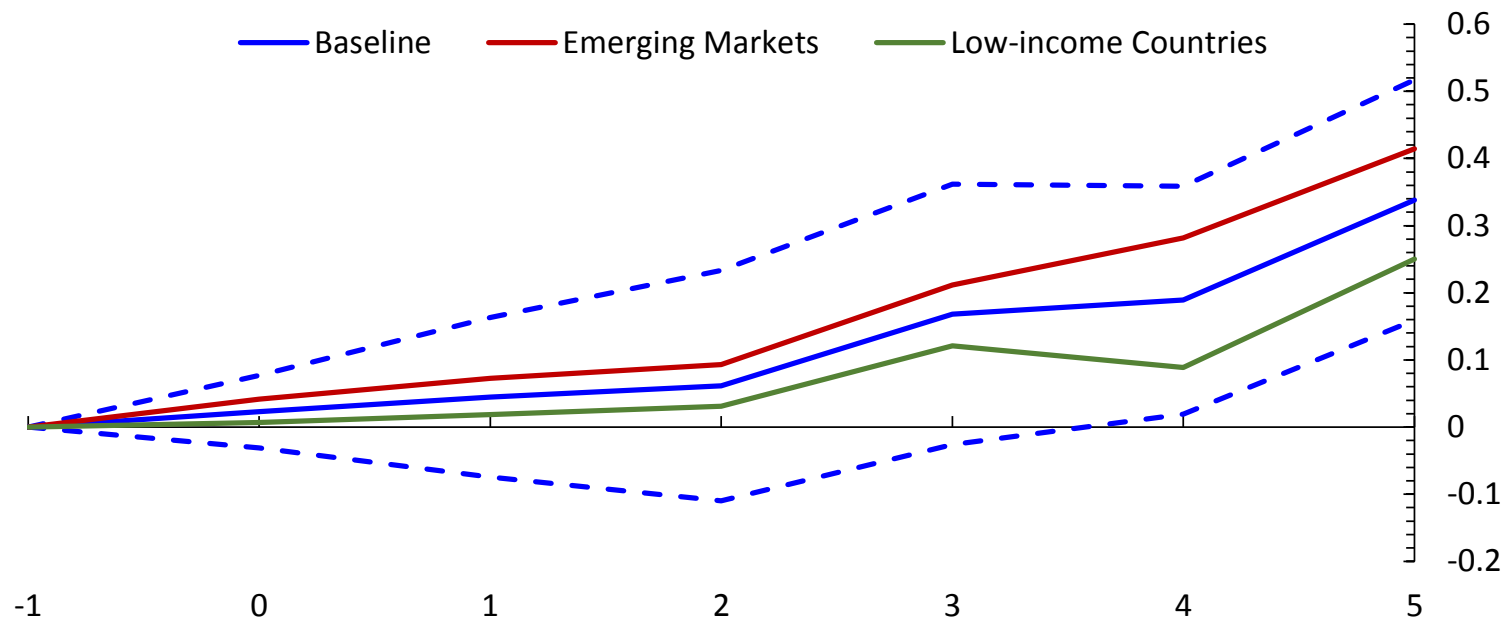

Note: $\mathrm{x}$-axes denote years; $\mathrm{t}=0$ is the year of the shock; the solid blue line denotes percent responses to an unanticipated 10 percent decrease in government expenditures in the baseline sample; dashed lines denote 90 percent confidence bands in the baseline sample; solid red and green lines denote alternative subsamples. Estimates based on equation (3).

Figure 6. Effect of an Unexpected Change in Government Expenditures on Net Income Inequality (Net Gini Coefficient)—Positive versus Negative Shocks

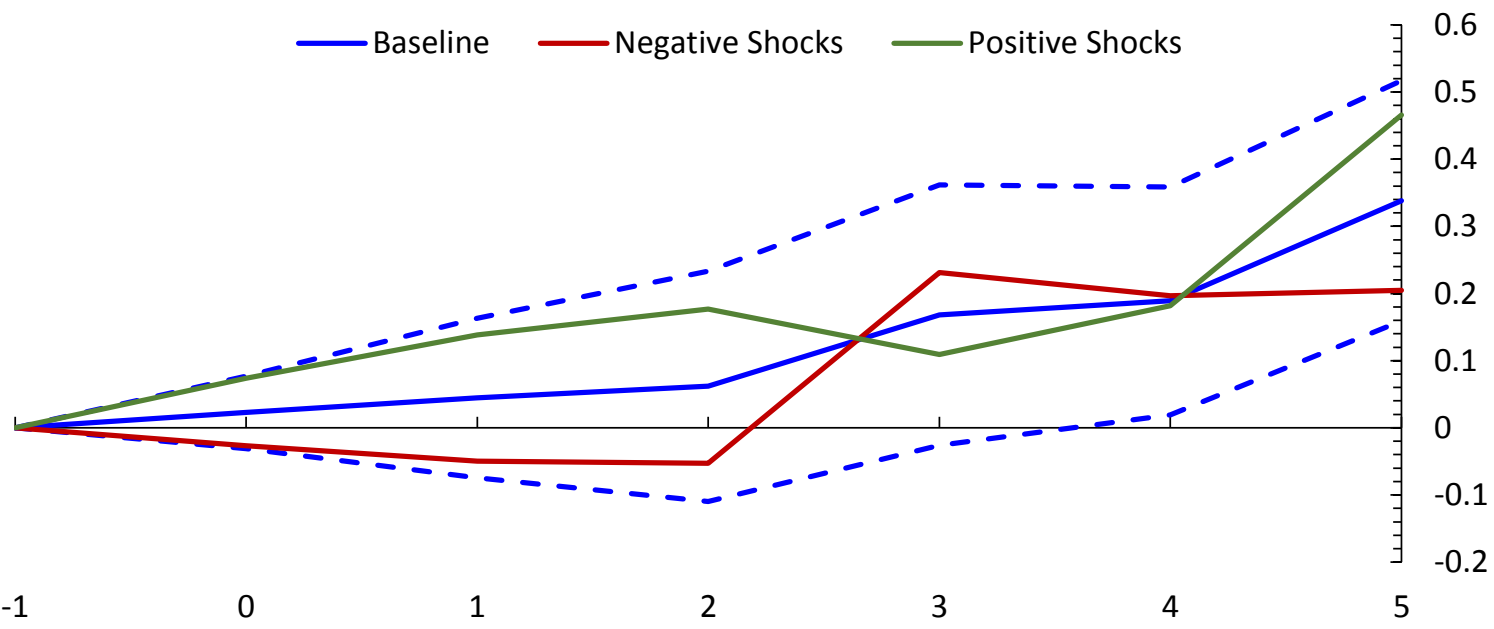

Note: $\mathrm{x}$-axes denots years; $\mathrm{t}=0$ is the year of the shock; the solid blue lines denotes percent responses to an unanticipated 10 percent decrease in government expenditures in the baseline model; dashed lines denote 90 percent confidence bands in the baseline model; solid red and green lines denote the response to negative and positive shocks, respectively. The response to positive shocks is reported with inverted sign to allow comparability. Estimates based on equation (3). 
Figure 7. Effect of an Unexpected Change in Government Expenditures on Net Income Inequality (Net Gini) — Large Positive versus Large Negative Shocks

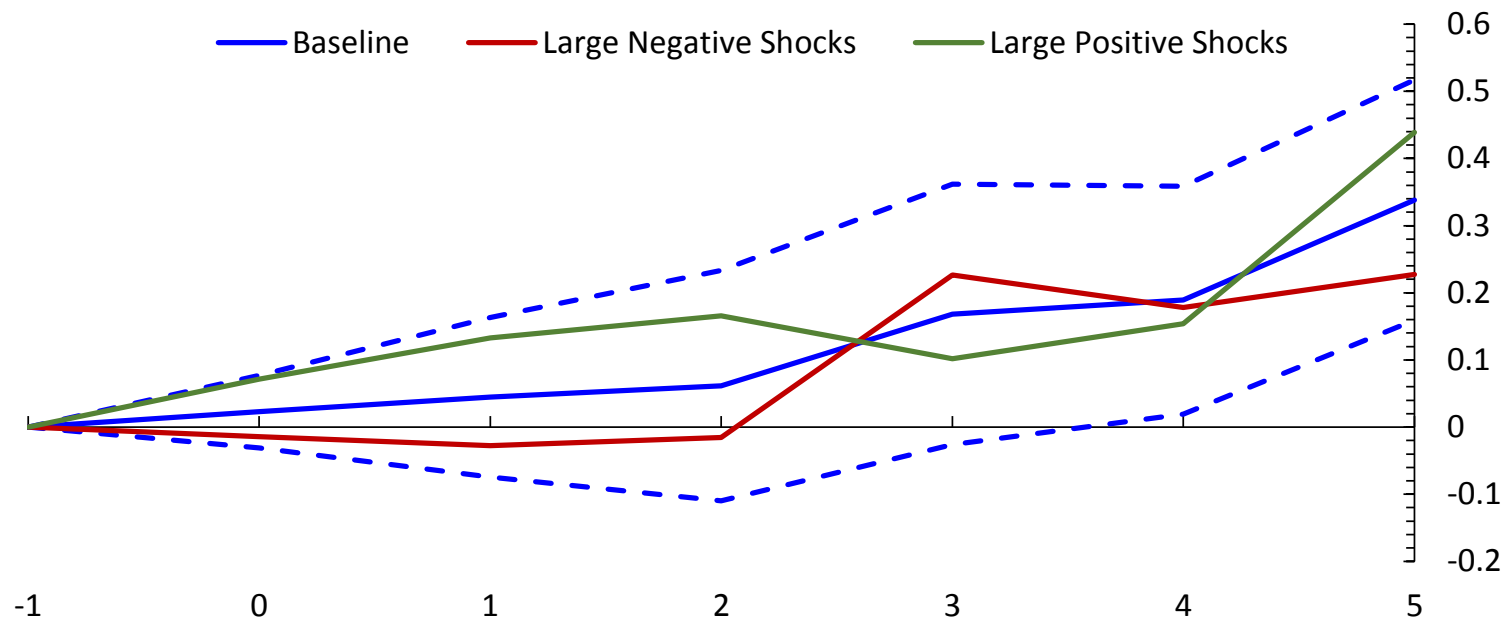

Note: $\mathrm{x}$-axes denote years; $\mathrm{t}=0$ is the year of the shock; the solid blue line denotes percent responses to an unanticipated 10 percent decrease in government expenditures in the baseline model; dashed lines denote 90 percent confidence bands in the baseline model; solid red and green lines denote the response to negative and positive shocks, respectively. The response to positive shocks is reported with inverted sign to allow comparability.. Estimates based on equation (4).

Figure 8. Effect of an Unexpected Decrease in Total Government Expenditures on Net Income Inequality (Net Gini Coefficient) - The role of the Business Cycle

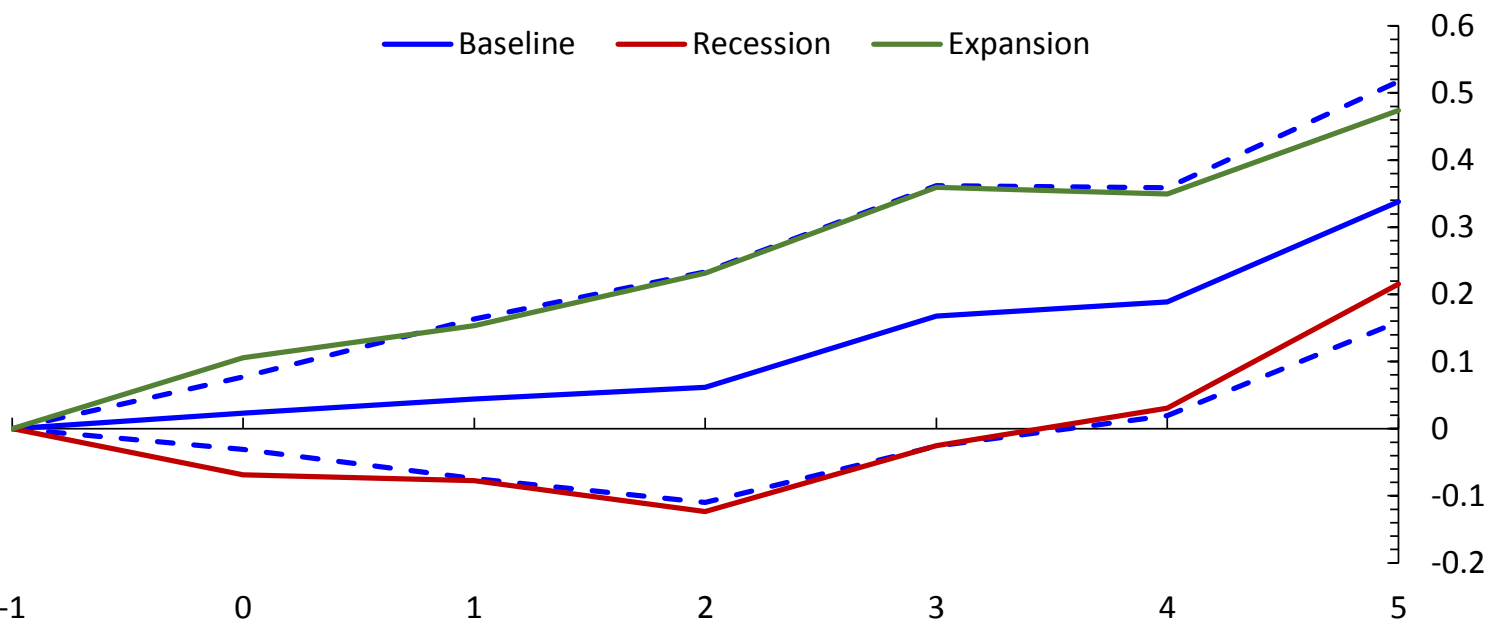

Note: $\mathrm{x}$-axes denots years; $\mathrm{t}=0$ is the year of the shock; the solid blue line denotes percent responses to an unanticipated 10 percent decrease in government expenditures in the baseline model; dashed lines denote 90 percent confidence bands in the baseline model; solid red and green lines denote alternative models. Estimates based on equation (5). 
Figure 9. Effect of an Unexpected Decrease in Government Consumption and Investment Net Income Inequality (Net Gini)
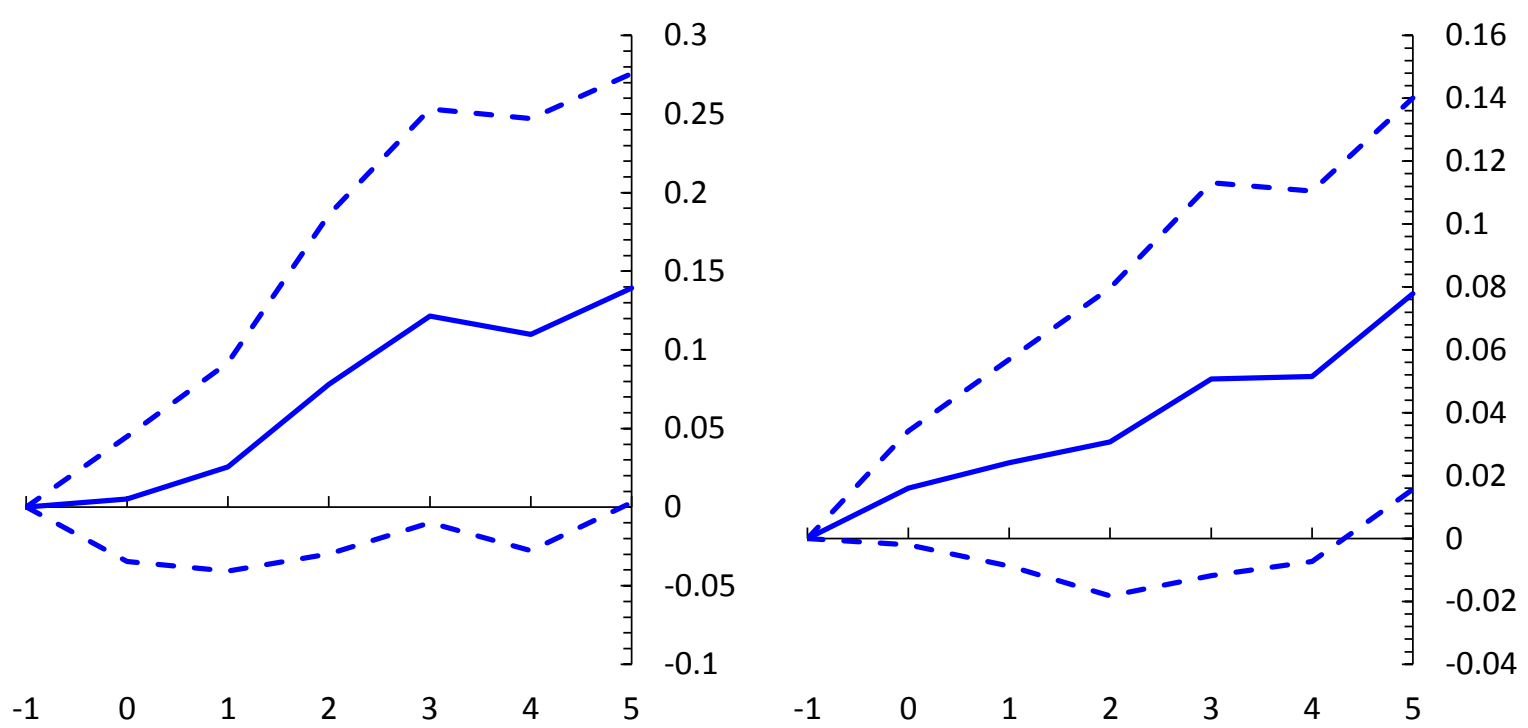

Note: $\mathrm{x}$-axes denote years; $\mathrm{t}=0$ is the year of the shock; solid blue lines denote percent responses to an unanticipated 1 percent decrease in government conmsumption (invesmtent); dashed lines denote 90 percent confidence bands. Estimates based on equation (2). 
APPENDIX

Table A1. Country Coverage

\begin{tabular}{|c|c|c|c|c|c|}
\hline Country & EM/LIC & Coverage & Country & EM/LIC & Coverage \\
\hline Afghanistan & LIC & $2005-2015$ & Lesotho & LIC & $1991-2015$ \\
\hline Albania & EM & $1993-2015$ & Lithuania & EM & $2000-2015$ \\
\hline Algeria & EM & $1990-2015$ & Macedonia, FYR & EM & $1995-2015$ \\
\hline Angola & EM & $1996-2015$ & Madagascar & LIC & $1990-2015$ \\
\hline Argentina & EM & $1990-2015$ & Malawi & LIC & $1992-2015$ \\
\hline Armenia & EM & $1995-2015$ & Malaysia & EM & $1991-2015$ \\
\hline Bangladesh & LIC & $1993-2015$ & Maldives & EM & $1993-2015$ \\
\hline Barbados & EM & $1992-2015$ & Mali & LIC & $1998-2015$ \\
\hline Belarus & EM & $2000-2015$ & Mauritania & LIC & $1999-2015$ \\
\hline Belize & EM & $1992-2015$ & Mauritius & EM & $1991-2015$ \\
\hline Benin & LIC & $1994-2015$ & Mexico & EM & $1990-2015$ \\
\hline Bolivia & LIC & $1990-2015$ & Moldova & LIC & $1995-2015$ \\
\hline Bosnia and Herzegovina & EM & $2003-2015$ & Mongolia & LIC & $1993-2015$ \\
\hline Botswana & EM & $1996-2015$ & Montenegro, Rep. of & EM & $2008-2015$ \\
\hline Brazil & EM & $1990-2015$ & Morocco & EM & $1990-2015$ \\
\hline Bulgaria & EM & $1995-2015$ & Mozambique & LIC & $1991-2015$ \\
\hline Burkina Faso & LIC & $1992-2015$ & Namibia & EM & $1996-2015$ \\
\hline Burundi & LIC & $1996-2015$ & Nepal & LIC & $2006-2015$ \\
\hline Cabo Verde & EM & $1996-2015$ & Nicaragua & LIC & $1992-2015$ \\
\hline Cambodia & LIC & $1999-2015$ & Niger & LIC & $1992-2015$ \\
\hline Cameroon & LIC & $1990-2015$ & Nigeria & LIC & $1991-2015$ \\
\hline Central African Republic & LIC & $1995-2015$ & Pakistan & EM & $1990-2015$ \\
\hline Chad & LIC & $1991-2015$ & Panama & EM & $2004-2015$ \\
\hline Chile & EM & $1990-2015$ & Paraguay & EM & $1991-2015$ \\
\hline China & EM & $2001-2015$ & Peru & EM & $1991-2015$ \\
\hline Colombia & EM & $1990-2015$ & Philippines & EM & $1990-2015$ \\
\hline Comoros & LIC & $1993-2015$ & Poland & EM & $1990-2015$ \\
\hline Costa Rica & EM & $2000-2015$ & Romania & EM & $1991-2015$ \\
\hline Croatia & EM & $1994-2015$ & Russia & EM & $1993-2015$ \\
\hline Côte d'Ivoire & LIC & $1990-2015$ & Rwanda & LIC & $1991-2015$ \\
\hline Djibouti & LIC & $1996-2015$ & Senegal & LIC & $1990-2015$ \\
\hline Dominican Republic & EM & $2001-2015$ & Serbia & EM & $2007-2015$ \\
\hline Ecuador & EM & $2002-2015$ & Seychelles & EM & $1991-2015$ \\
\hline Egypt & EM & $1990-2015$ & Sierra Leone & LIC & $1996-2015$ \\
\hline El Salvador & EM & $1992-2015$ & South Africa & EM & $1990-2015$ \\
\hline Ethiopia & LIC & $1998-2015$ & Sri Lanka & EM & $1990-2015$ \\
\hline Gambia, The & LIC & $1990-2015$ & Swaziland & EM & $1996-2015$ \\
\hline Georgia & EM & $2010-2015$ & Syria & EM & $1992-2010$ \\
\hline Ghana & LIC & $1990-2015$ & Tanzania & LIC & $1998-2015$ \\
\hline Guatemala & EM & $1993-2015$ & Thailand & EM & $1990-2015$ \\
\hline Guinea & LIC & $1992-2015$ & Togo & LIC & $1991-2015$ \\
\hline Guinea-Bissau & LIC & $1996-2015$ & Trinidad and Tobago & EM & $1991-2015$ \\
\hline Haiti & LIC & $1992-2015$ & Tunisia & EM & $1991-2015$ \\
\hline Honduras & LIC & $1994-2015$ & Turkey & EM & $1990-2015$ \\
\hline Hungary & EM & $1990-2015$ & Uganda & LIC & $1996-2015$ \\
\hline India & EM & $1990-2015$ & Ukraine & EM & $1998-2015$ \\
\hline Indonesia & EM & $1990-2015$ & Uruguay & EM & $1993-2015$ \\
\hline Iran & EM & $1992-2015$ & Venezuela & EM & $1990-2015$ \\
\hline Kazakhstan & EM & $2004-2015$ & Vietnam & LIC & $1998-2015$ \\
\hline Kenya & LIC & $1990-2015$ & Yemen & LIC & $2001-2015$ \\
\hline Kyrgyz Republic & LIC & $1999-2015$ & Zambia & LIC & $1991-2015$ \\
\hline Lebanon & EM & 2001-2015 & & & \\
\hline
\end{tabular}

Notes: $\mathrm{EM}=$ emerging market; $\mathrm{LIC}=$ low-income country. Classification based on IMF WEO. 
Figure A1. Distribution of Government Expenditure Shocks in EMDE (Source: IMF World Economic Outlook and IMF Staff calculations)

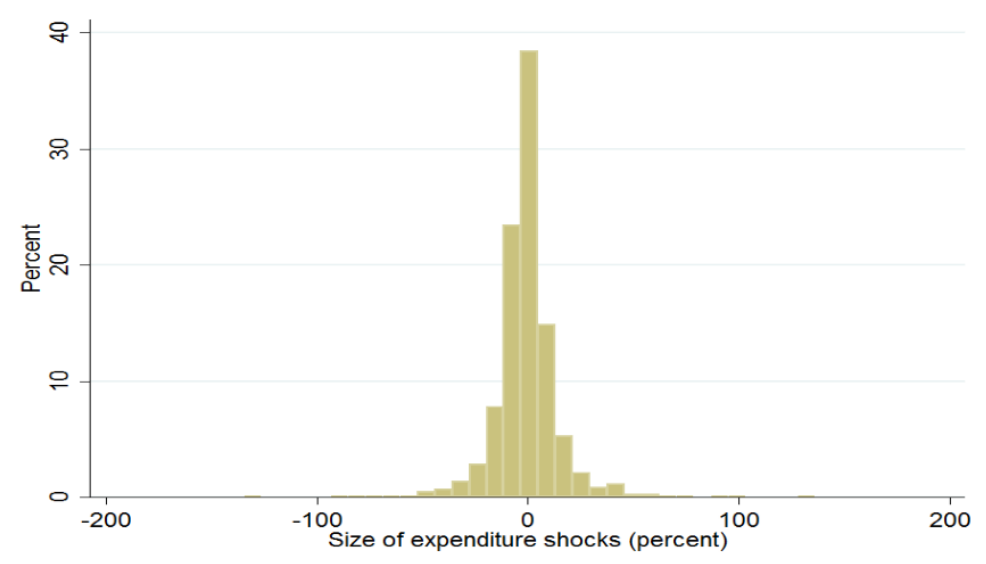

Figure A2. Distribution of Government Consumption Shocks in EMDE (Source: IMF World Economic Outlook and IMF Staff calculations)

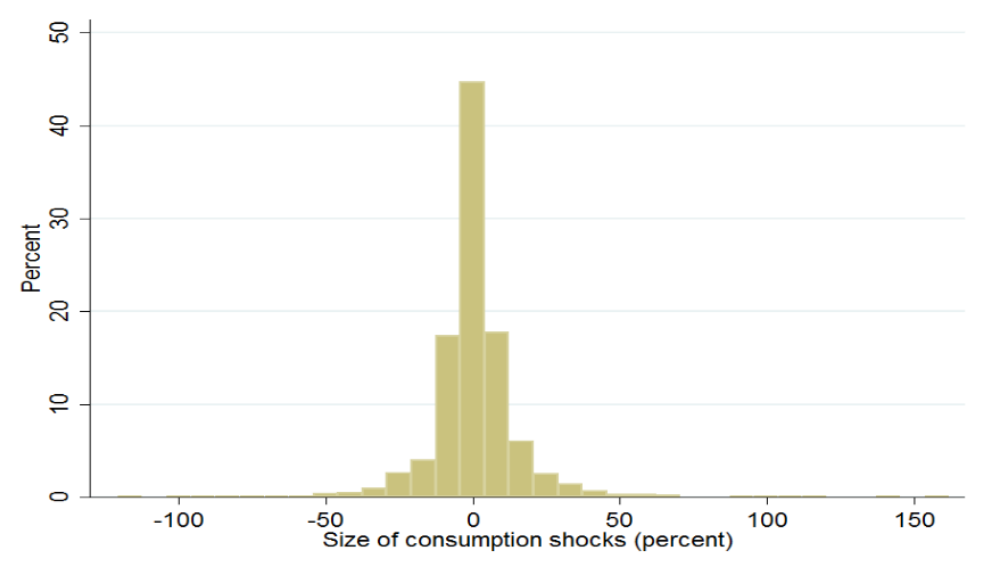

Figure A3. Distribution of Government Investment Shocks in EMDE (Source: IMF World Economic Outlook and IMF Staff calculations)

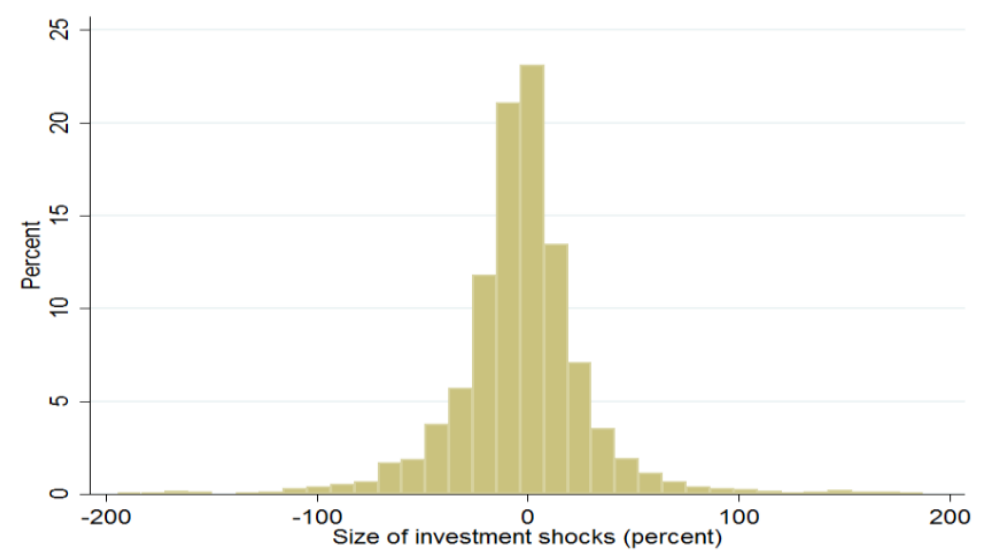

CInternational Monetary Fund. Not for Redistribution 